\title{
Didysis karas: diskursai ir atminimo praktika tarpukario Lietuvoje
}

\author{
VYTAUTAS JOKUBAUSKAS \\ Klaipedos universiteto Baltijos regiono istorijos ir archeologijos institutas, \\ Herkaus Manto g. 84 (VI korpusas), LT-92294 Klaipeda \\ El. paštas pilsotas@yahoo.com
}

\begin{abstract}
Straipsnyje (1) analizuojami Didžiojo (Pirmojo pasaulinio) karo diskursai ir atminimo kultūros praktika tarpukario Lietuvoje. Tyrime aptariama grožinès literatūros Didžiojo karo tema kiekis tarpukario Lietuvoje ir jos pobūdis (atkreipiant demesị i verstinių ir vietinių autorių kūrinių lygị, literatūros karo tema "pakilimą" ir pokyčius), šio karo reikšmè visuomenei; atskleidžiama Didžiojo karo sukakčių minejjimų ir karių kapų tvarkymo praktika tarpukario Lietuvoje.
\end{abstract}

Raktažodžiai: Didysis (Pirmasis pasaulinis) karas, diskursas, karių kapai, literatūra karo tema, karo nuostoliai, Lietuvių-prancūzų draugija

Didysis (Pirmasis pasaulinis) karas ịvardytinas atskaitos tašku, reiškiniu, kai „viskas“ vyko „prieš“ arba „po karo“, tačiau kartu ir tam tikra laiko atkarpa, kuri iš esmès pakeite žmonių gyvenimą, ịsitvirtino atmintyje, o tarpukariu buvo ịvairių diskursų sudedamoji dalis. Pabrěžtina, kad Didysis karas turėjo svarų poveikị Lietuvos visuomenei ir jam pasibaigus. 1934 m. rašyta: „Didysis karas pasibaigè, negaudžia patrankos, nežvanga ginklai, bet dar ilgus metus tautoms teks sunkiai kovoti su baisiomis Didžiojo karo išdavomis. Tai irgi savo rūšies karas" $[63,351]$. Taigi Lietuvos visuomenei teko kariauti tą karą bandant atsakyti, ką jis reiškè Lietuvai, ìvertinti jo padarinius. Pagaliau, susidurta su emocinių traumų pasekmėmis, o visa šalis buvo nusèta aukų kapais.

Didysis karas buvo pati masiškiausia žmonijai iki tol žinoma ginkluota kova. Jis lèmé kare dalyvavusių valstybių užsienio ir vidaus politiką. Ieškota bendrų vardiklių, pavyzdžiui, kaip karas vertintas kitose šalyse - Vokietijoje, Prancūzijoje ar Didžiojoje Britanijoje. Praejjus šimtmečiui po Didžiojo karo dažnai manome, kad tarpukariu Lietuvoje Pasaulinis karas nebuvo aktualus, palyginti su nepriklausomybès paskelbimu ir kovomis dèl jos. Tačiau galbūt tai tik XXI a. interpretacija, labiau išreiškianti esamas realijas, o ne tarpukario padètị?

Tyrimo tikslas - nustatyti Didžiajam karui teikiamą reikšmę tarpukario Lietuvoje; tam bus tiriami tarpukario diskursai ir Didžiojo karo atminimo praktika (ar jos apraiškos).

(1) Straipsnis parengtas ịgyvendinant Lietuvos mokslo tarybos finansuojamą mokslininkų grupių projektą „Pirmojo pasaulinio karo atminimas: Lietuvos ir Rytprūsių lyginamoji analizė (iki 1939 metų)“ (MIP-021/2015). 
Tyrimo uždaviniai:

1) išnagrinèti Didžiojo karo vietą viešuosiuose diskursuose tarpukario Lietuvoje;

2) atskleisti tarpukario atminimo kultūros praktiką Lietuvoje, susijusią su Didžiojo karo paminejjimu ir jo karių kapų tvarkymu.

Tyrimo chronologinès ribos - tarpukaris, 1919-1940 metai. Susitelkiama į vieną atveji, o lyginamoji analize paliekama ateities tyrimams. Straipsnyje analizuojami Didžiojo (Pirmojo pasaulinio) karo diskursai ir atminimo kultūros praktika, taikyta tarpukario Lietuvoje. Čia nesiekta aprèpti visą su karu susijusią literatūrą, ịmanomus diskursus ar praktiką. Tai jau būtų atskiros studijos ar monografijos lygio darbas.

Kai kurie tyrimui aktualūs aspektai, pvz., edukaciniai - bendrojo lavinimo programos, mokymo priemonès bei muziejų kolekcijos ir ekspozicijos, bus analizuojami vèlesniame vykdomo projekto („Pirmojo pasaulinio karo atminimas: Lietuvos ir Rytprūsių lyginamoji analizè (iki 1939 metų)") etape. Šio teksto kontekste itin svarbūs Pirmūnų sąjungos ir karo invalidų analizès klausimai (2), nes jų visuma leidžia perprasti Didžiojo karo vietą bei vaidmeni Lietuvos valstybès ir visuomenès gyvenime tarpukariu. Apskritai Didysis karas ar su jo atminimo kultūra bei ịvaizdžiais susijusios problemos XXI a. Lietuvos istoriografijoje nèra itin populiari tema $[61 ; 65 ; 109 ; 110 ; 213 ; 222 ; 251]$.

\section{DIDŽIOJO KARO SIUŽETAI LITERATŪROJE}

Didysis karas tapo grožinès literatūros siužetų pagrindu. $1930 \mathrm{~m}$. suomių poetas ir prozininkas Henry'is George'as Williamas Parlandas, kelerius metus gyvenęs Kaune, Vaire rašè: „Didysis karas kūliomis apvertė karo filosofiją. Jis nušlavè paskutinius Viduramžių siekiančius individualios dvikovos pẻdsakus ir asmenybès vietoje pastatè visai kitas sąvokas: masės ir technikos.“ Autorius pabrèžè, kad Didžiajame kare nebedalyvavo asmenybès, o tik kolektyvai ir kariuomenès, kuriose nebebuvo senojo herojinio tipo didvyrių. Naujasis didvyrio vaizdinys - „paprastas vidutinis žmogus“ [169, 261-262]. 1934 m. literatūrologas, kritikas, žurnalistas ir rašytojas Julius Būtènas teigè, kad „tik iš Didžiojo karo pasaulis tikrai pažino karą, tik Didijji karą vaizduodami rašytojai aprašè tikrą karą" [37]. Aptaręs grožinę literatūrą Didžiojo karo tema Prancūzijoje, Vokietijoje, Didžiojoje Britanijoje, JAV, SSRS, Bulgarijoje, Vengrijoje ir Čekoslovakijoje, konstatavo, kad lietuvių literatūra po karo „tik kvapą atgauna“. Paminèjęs Maironị („Mūsų vargai“), Vydūną („Pasaulio gaisras“), Jono Norkaus sudarytas Didžiojo karo laiku lietuviu dainas, kuriose perteiktos lietuvių patirtys karo metu, Antaną Vienuolị („Prieš dieną“), jis pabrèžè, kad „senesniesiems mūsų rašytojams“ daugiau žinomas karo pabėgèlių Rusijos imperijos gilumoje gyvenimas ir kad „vertesnès karo literatūros galima laukti iš naujųjų rašytojų, kuriems teko vokiečių okupacija ir visa kita pergyventi vietoj“. J. Būtėnas pateikè kelis pavyzdžius: Jono Šimkaus apysaką „Nuvirtus beržams“, Juozo Tarvydo „Per audrą“, Petro Vaičiūno „Liepsnojančios širdys“ [38]. Kiek vẻliau daugiau „kariškų motyvų“ buvo įžvelgiama Liudo Giros ir Kazio Binkio kūryboje [157]. J. Būtèno teigimu, grožinès literatūros Didžiojo karo tema bruožas tarpukariu buvo joje vyraujantys klausimai: „dèl ko kariaujama, kam reikalingas karas, kaip karų ir viso būtų galima išvengti“, o ypač „karo scenų baisumo, šiurpumo vaizdavimas“, nes, anot jo, šios literatūros gerbejai knygas vertino pagal tai, kaip jose pavyko atskleisti fronto realybę [39]. Analizuotos karinès dainos ir tai, kaip jose XX a. pirmojoje pusèje buvo „sugrąžintas“ kario herojaus įvaizdis, karo

(2) Plačiau žr. kituose V. Jokubausko parengtuose straipsniuose vykdant LMT projektą MIP-021/2015. 
filosofija Vydūno ir Vaižganto darbuose, nes „gilesnès karo prasmès ieškoti ypačiai pastūmejjo Didysis karas“ [8].

Didžiojo karo tema tarpukariu grožinèje literatūroje išties buvo ryški. Vienas pirmųjų romanų buvo Adrieno Gustave’o Henrio Barbusse’o Le Feu („Ugnis“), išleistas 1916 metais. 1914 m. savanoriu stojęs ị Prancūzijos kariuomenę, fronte sužeistas ir demobilizuotas, autorius, remdamasis savo patirtimi, parašè šią knygą dar tebevykstant karui. Būtent A. G. H. Barbusse'as pirmasis pasauliui atskleidè tikrąji karo veidą [37, 408]. $1920 \mathrm{~m}$. Vokietijoje pasirodžiusi Ernsto Jüngerio knyga In Stahlgewittern lietuvių kalba buvo išleista tik 2016 m. [88].

Lietuvos kariuomenès Vyriausiojo štabo Karo mokslo valdyba 1926 m. išleido Didžiojo karo legendinio lakūno - „raudonojo barono“ Manfredo Albrechto Freiherrio von Richthofeno autobiografinę knygą Raudonasai karo lakūnas (vok. Der rote Kampfflieger), kurioje autorius dalijasi savo išgyvenimais taikos ir karo metu. Vertejjas vyr. ltn. Jonas Pyragius savo ịvadiniame žodyje teigè, kad knygą išvertė noredamas visuomenę ir karius supažindinti su aviacijos veikla Didžiajame kare [202]. A. G. H. Barbusse’o romanas Ugnyje lietuvių kalba išleistas 1928 m. (JAV) [18] (3), o 1934 m. Lietuvos žurnalas Kultūra išspausdino šio romano ištrauką „Mirtis dumble“ [17]. 1929 m. Lietuvoje lietuvių kalba buvo išleistas tikriausiai garsiausias romanas apie Didijji karą - Ericho Maria’ios Remarque'o Vakaru fronte nieko naujo [201]. Tais pačiais $1929 \mathrm{~m}$. Lietuvoje pasirodè ir 2-asis jo leidimas. Autoriui pranašaujant Nobelio premiją, Karde apie knygą rašyta: „neseniai išejusi Remarko knyga buvo tikra literatūros sezono sensacija. Kalbèta apie ją nemažai. Kiekvienas jautėsi turịs teisès autoritetingai kalbėti apie veikalą, kurio siužetas paimtas iš karo ir daugiausia fronto gyvenimo. Mat, kiekvienas mūsų kartos vyriškis yra ar tai betarpiškas didžiojo karo dalyvis, ar bent artimas visų karo ir pokarinių ịvykių liudininkas, todèl kiekvienam šios knygos tema prieinama visose savo detalèse" $[259,112]$. Spaudoje, aptariant po Didžiojo karo išpopuliarejjusius romanus karo tema, ị jų turinị buvo pažvelgta kritiškai, nes „karą pažinusiems, ji pergyvenusiems, o svarbiausia jame dalyvavusiems, ypač Remarko vaizdai sukelia rimtų abejojimų dèl jų tikrybės“ [245, 39]. Tačiau E. M. Remarquéo kūriniai Lietuvos skaitytoją domino ir vẻliau: 1931 m. pasirodè Kelias atgal [199], kurị išleido dvi leidyklos (abi dalis išleido „Sakalo bendrové, o I dalis išèjo ir kaip „Naujo Žodžio“ leidinys, verstas to paties vertèjo Broniaus Railos [155]), 1939 m. išleistas trečiasis šio autoriaus romanas Didžiojo karo tematika - Trys draugai [200].

1929 m. Trimite, pažymint, kad suejo dešimt metų, kaip „vokiečiai išsikraustè iš Kauno“, buvo paskelbta ištrauka iš Kaune, Ober Osto spaudos skyriuje, tarnavusio Vokietijos kario Arnoldo Zweigo romano "Ginčas dèl seržanto Grišos" (Der Streit um den Sergeanten Grischa, 1928) [44] (4). 1931 m. Lietuvoje buvo išleistas buvusio Rusijos kariuomenès kazokų karininko Chadži-Murato Mugujevo romanas Ir Rytu fronte nieko naujo (И на восточном фронте без перемен: врата Багдада), 1929) [148], kurio pavadinimą, matyt, nulèmé E. M. Remarque’o knygos sèkmè. Ch.-M. Mugujevo romane aprašomi kazokų šimtinės nuotykiai keliaujant per dykumą Bagdado link, kur jie turèjo susijungti su

(3) Kitas šios knygos leidimas lietuvių kalba pasirodė 1954 m. [19].

(4) Pristatant knygą rašyta, kad joje ,jaudinančia gyvenimo teisybe aprašytas vokiečių okupantų žiaurumas mūsų šaly. Visas romano veiksmas vyksta Lietuvoj, tada Ober-Oste. Čia ir pabėgąs rusų belaisvis Griša, ir besislapstą Lietuvos miškuose vokiečių dezertyrai, ir iš žandarų nagų ištrūkę lietuviai. Jiems visiems vadovauja jauna, bet jau pražilusi lietuvaite““ [44]. 
Didžiosios Britanijos pajègomis. Knygoje neliečiami karių išgyvenimai ar kiti psichologiniai aspektai, bet pasineriama ị nuotykių Didžiojo karo metu aprašymą [41]. Trečiasis verstinis kūrinys apie Didijj karą Lietuvoje buvo $1931 \mathrm{~m}$. pasirodęs Didžiojo karo veterano, prancūzų autoriaus Roland’o Dorgelès romanas [55] Mediniai kryžiai (Les Croix de bois, 1919) [53]. 1932 m. išleistos amerikiečių autoriaus Williamo T. Scanlono knygos [217] lietuviško varianto paantraštejje skelbta, kad tai „amerikonų Vakaru fronte nieko naujo" versija. Tai, žinoma, galima vertinti kaip rinkodaros sprendimą pasinaudoti E. M. Remarque'o romano populiarumu ir suvilioti Lietuvos skaitytoją ịsigyti ir W. T. Scanlono kurinị. 1932 m. lietuvių kalba išleista Jeroslavo Hašeko kūryba, demonstruotas jos pagrindu sukurtas filmas [67; 68; 84] (5). Prancūzų rašytojas F. G. Lebos, kelių romanų autorius, karo priešininkas, romaną Nekaltuju kraujas (Le Sang des innocents, 1934) išleido Didžiojo karo 20 metų sukakčiai paminèti [156, 799]. Jau kitais metais išversta ir išleista Lietuvoje ši knyga [122] ir jos vertimas ị lietuvių kalbą sulaukẻ kritikos pažymint, kad Lietuvos skaitytojai „vertimais labiau pasitiki, negu savąja originaline literatūra, tad pastaruoju laiku vertimų nemaža spausdinama“" [34]. 1933 m. Niujorke lietuvių kalba buvo išleista SSRS rašytojo Moisejjaus Gromovo apysaka Karas Lietuvoj: anot vertejo D. M. Šolomsko, Pirmojo pasaulinio karo „naikinimo liepsna apėmė ir Lietuvą, iki šiolei mes neturèjome rimtesnio kūrinio, nušviečiančio jo vaizdus“ [268].

Tarpukariu nebuvo apsiribojama verstinès literatūros Didžiojo karo tema leidyba, Lietuvos autoriai taip pat įnešè savo indèlį. Petronèlè Bartninkaitė-Rūtelionienė $1930 \mathrm{~m}$. pradejo leisti keturių dalių romaną Klaikuma: iš Didžiojo karo laiku ir tremtiniu gyvenimo [21]. Pasirodžius 1-ajam tomui, Vytautas Steponaitis apie knygą atsiliepė šitaip: „Didysis karas tiek pakeitè ne tik atskirų žmonių gyvenimą, bet ir bemaž visos žmonijos, kad nestebètina, jogei tuo reikalu pasisakè nemaža rašytojų. Bet ši posakị labiau galima taikinti užsieniams, o ne mums. Plačiau tuo klausimu (smulkesnių apysakučių, aprašymèlių neturiu galvoj) pas mus pirmą kartą išsitaria Rūtelionienè. “ Pažèręs autoriai nemažai dalykinių pastabų, recenzentas vis dèlto apibendrino: „iš šio tomo sprendžiant pati autorè kol kas klaikumoj klaidžioja" [225].

1931 m. pasirodè Onos Pleirytės-Puidokienès, aktyvios lietuvių pabėgèlių Sibire veikejos [144], knyga, kurios 2-ojoje dalyje pateikti apsakymai apie i Rusijos imperijos gilumą nuo Didžiojo karo pabėgusius lietuvius [183]. $1932 \mathrm{~m}$. su autoriaus dedikacija „Tiems, kurie kovoja dèl taikos“ buvo išleista Antano Skripkausko knyga Romanas be moters: epizodas iš Didžiojo karo laiku [220], kuri autoriaus sūnų iniciatyva buvo perleista 2004 m. [146]. Knygoje Didžiojo karo patirtys Lietuvoje perteikiamos iš nedidelès kaimo bendruomenès, i̦sikūrusios ant Šventupio upelio kranto Šiaulių apskrityje, pozicijų. 1935 m. publikuotas Antano Krasausko romanas Mirtis už fronto [118]. Rusijos kariuomeneje

(5) „Spaudos fondas“ išleido knygą Šaunusis kareivis Šveikas (knygos nepavyko aptikti nè viename Lietuvos bibliotekų kataloge, taip pat $1932 \mathrm{~m}$. Bibliografijos žiniose, todèl galbūt tai yra tas pats leidinys) sutrumpintą Šauniojo kareivio Šveiko nuotykiu pasauliniame kare versiją (Hašek, J. Šaunusis kareivis Šveikas. Kaunas: Spaudos fondas, 1932). Tais pačiais metais „Naujasis Žodis“ ši kūrinį išleido kaip savo priedą (Hašek, J. Šaunusis kareivis Šveikas: Šveikas ruošiasi kariauti. Kaunas: Naujasis Žodis, 1932); Jaroslav Hašek [1883-1923] Bibliografie. [2016 08 28]. Prieiga per internetą: <http://comenius-bibl.wz.cz/Hasek.html> ; Istorija. Žvelkime kartu. [2016 08 28]. Prieiga per internetą: <http:// www.istorija.tv/sausio-3-istorijoje/>; „Naujojo Žodžio“ leidinyje „paimta tik maža dalis šio veikalo, būtent, nuo to, kai „Šaunusis kareivis Šveikas“ patenka ị policijos valdybą (po Austrų-Vengrų erchercogo Ferdinando užmušimo Sarajeve) iki jis, paleistas iš karo kalejjimo, patenka pas kalëjimo kapelioną pasiuntiniu" [84]. 
tarnavęs Stasys Keblas, Didžiojo karo veteranas, buvo sumanęs leisti keturių dalių veikalą „Pasaulio atmaina“: 1935 m. pasirodè romanas Pasauliniame fronte... Ekstra telegrama!, 1936 m. - Pasaulinis karas, 1939 m. parašyta trečioji dalis „Revoliucija, chaosas, krize“ dèl prasidejusio Antrojo pasaulinio karo liko neišleista. Autorius buvo pradejjęs rašyti ir ketvirtąją dali - „Antichristija“, tačiau šis rankraštis, kaip ir 3-iojo tomo, pražuvo $1944 \mathrm{~m}$. [171]. Pirmojo tomo pratarmèje pažymèjęs, kad lietuvis daug išgyvenęs ir kovojęs su priešais „už savo brangią Tẻvynę Lietuvą" dabar trokšta tų kovų „fotografijos“, S. Keblas pasižadejo: „pasaulinio karo eigos nuotrauką aš tau, lietuvi, nuo širdies čia ir žadu teikti. Skaityk pats, kitam skaityti duok ir puošk, jei tiks savo kambarị, knygyną ar knygynèlį“ [112]. Antras tomas buvo dedikuotas „Lietuvos atgimimo Pranašui Mačiuliui-Maironiui“ [113]. Romano siužetas karinis. Pirmame tome aprašoma 1914 m. mobilizacija Lietuvoje, antrajame karo veiksmas apima ir Kauno tvirtovę bei Rytų Prūsiją. 1937 m. išleistame Adomo Bytauto romane Senosios pilies paslaptis veiksmas vyksta 1915-1916 m. žiemą Rusijos ir Vokietijos fronte [27]. Ieva Simonaitytė išleido lietuvių literatūros klasika tapusị romaną Vilius Karalius [218], kuriame gana ryški Didžiojo karo siužetinè linija. Voroneže gyvenęs Pirmojo pasaulinio karo pabėgèlis Salys Šemerys (Saliamonas Šmerauskas) karo tema parašè eilèraštị „Balade்“ [234]. 1927 m. buvo išleista jau minèta Jono Norkaus knyga Didžiojo karo laiku lietuviu dainos, kurioje nurodoma dainų užrašymo vieta ir metai, jų siužetai - vargai, aukos, mobilizacija [48]. 1937 m. publikuotas Petro Mižutavičiaus eilèraštis Didžiojo karo Lietuvoje tema „Dubysa - karo tvirtove““ [54] (6).

Nemažai paskelbta prisiminimų, ypač karineje literatūroje - žurnaluose Mūsų senovè ir Karo archyvas (7). Iš dalies tai buvo Lietuvos Kariuomenės štabo Spaudos ir švietimo skyriaus Istorijos dalies kryptingos veiklos rezultatas, nes aktyviai agituota (8) ir netgi ieškota asmenų, kurie galètų parašyti prisiminimus apie karą (rinkti 1863-1864 m. sukilimo, Didžiojo karo ir nepriklausomybès kovų prisiminimai). $1936 \mathrm{~m}$. Istorijos dalies vedèjas plk. ltn. Vytautas Steponaitis laiške dèl prisiminimų apie Pagirių partizanų veiklą prašè: „gal galètumète parašyti atsiminimus iš vokiečių okupacijos laikų?" [246].

1920 m. JAV buvo išleista kunigo Jurgio F. Jonaičio knyga Mano Patyrimai Didžiojoj Karēj 1918 ir 1919 metais [87], o 1927 m. kita jo knyga Keturi angelai, kurioje savo ìspūdžius grịžęs ị Lietuvą pasakoja Vakarų fronte, Prancūzijoje, kariavęs karininkas; iš turinio galima suprasti jog tai - lietuvis, tarnavęs JAV kariuomenejje [86]. Atskiromis knygomis 1933 m. buvo išleisti karininkų Leono Lingvevičiaus atsiminimai apie karą [134] ir gen. Leono Radus-Zenkavičiaus prisiminimai (pastarieji vokiečių kalba Klaipėdoje [193]). Civilių prisiminimai sugule ị Pranciškaus Žadeikio Didžiojo karo užrašus ir Gabrielès Petkevičaitès-Bitès Karo meto dienoraščius, kurie pastaraisiais metais buvo perleisti. 1939 m. buvo išleista Petro Rusecko sudaryta prisiminimų apie Didiji karą knyga - Lietuva

(6) Prie jo buvo įdèta Kario redakcijos pastaba: „šis eilèraštis nèra kokio nors poeto parašytas, bet paprasto kaimiečio, Didžiojo karo dalyvio, kuriam teko kautis prie Dubysos. Ir iš eiliavimo formos pastebėsite, jog jis yra artimas liaudies kūrybai. Nors eilèraštis ir turi trūkumų, bet jị dedame kaip Didžiojo karo atsiminimą ir mūsų liaudies vèlesniųjų laikų kūrybos pavyzdį“ [54].

(7) 1921 m. rašyta, kad „kai kuriose Žemaičių vyskupijos klebonijose nuo pat [Didžiojo] karo pradžios kasdien surašomi svarbesnieji atsitikimai. Surinkta labai daug medžiagos. <...> Sąrašai skiriami Lietuvos istorijos karo metų aprašymui“ [102].

(8) „Taip pat geistini vokiečių ir kitų okupacijų periodų atsiminimai“ [103]; „Kariuomenės štabo Karo Istorijos Dalis jau kartą kreipèsi ị Didžiojo ir mūsų Nepriklausomybès karų dalyvius, prašydama surašyti savuosius atsiminimus ir juos prisiųsti karo Istorijos Daliai. Be to, nemažam skaičiui asmenų buvo pasiųsti paraginimo laiškai“ $[162 ; 104]$. 
Didžiajame kare [124], tačiau istorikas Zenonas Ivinskis i ją pažvelgè kritiškai, nedaug vertès matydamas tuose prisiminimuose. Visgi jo parengta recenzija spaudoje nepasirodè, o Z. Ivinskis ant savo juodraščio užrašè: „Cenzūra 1940 m. vasarị liepé išmesti, nors jau buvo surinkta dèti į Židinį“ [60, 329].

Vakarų autoriai - A. G. H. Barbusse’as, E. Jüngeris ir E. M. Remarque’as - buvo kariai, Didžiojo karo dalyviai, savo kūryboje perteikę ir asmenines patirtis bei išgyvenimus; jų kūriniai parašyti prisiminimų pagrindu. Beje J. Hašekas, knygos Šauniojo kareivio Šveiko nuotykiai pasauliniame kare autorius, taip pat buvo Didžiojo karo dalyvis, dezertyravo iš Austrijos-Vengrijos kariuomenès ir tapo čekų legionieriumi. Lietuvoje tarpukariu tokio lygmens kūrinių apie Didijji karą išleista nebuvo. Nebent galime paminèti Didžiojo karo dalyvio, 1915 m. vasario mèn. Augustavo miškuose i Vokietijos nelaisvę patekusio plk. Aleksandro Uspenskio, kuris 1918-1926 m. tarnavo Lietuvos kariuomeneje, 1932 m. rusų kalba išleistą knygą, kuri 1935 m. buvo perleista lietuviškai - Didžiajame kare Lietuva - Rytų Prūsija 1914-1915 m. Karininko atsiminimai [243]. Pažymètina, kad knyga sulaukè teigiamų vertinimų [13; 30; 262], buvo išversta ị čekų kalbą. Gen. št. plk. Vlado Skorupskio nuomone, „kiekvienam kariui ir piliečiui pageidautina perskaityti tą knygą, kad jis žinotų 1914-1915 metais ịvykusias Rytų Prūsijoje ir Lietuvoje karo baisybes“ [219]. 1934 m. poetas, rašytojas, dramaturgas ir žurnalistas, keturvéjininkų grupès iniciatorius Kazys Binkis rašè, kad Lietuvos leidejjai verčia vokiečių ir prancūzų autorių knygas, bet nepastebi daug aktualesnio kūrinio, kuriame aprašomas veiksmas Lietuvoje. K. Binkio vertinimu, autorius „savo aprašymo paprastumu vietomis pasiekia meistriškumo. Kai skaitydamas Remerką jauti tyčia sugrupuotus faktus, sutirštintus dažus, - čia visai nepastebima autoriaus pastangų ką nors gąsdinti karo baisenybėmis, čia matai pačią baisią tikrovę, pilną heroizmo, pasiaukojimo, kančių, pagaliau beprasmiškumo ir klaikumo." K. Binkio nuomone, A. Uspenskis savo tekstu prikausto skaitytojo dèmesị, kuris kartu su autoriumi keliauja iš Vilniaus ị frontą ir belaisvių stovyklą. K. Binkis knygą îvertino taip: „žymus veikalas“ [26].

\section{KARIŲ PATIRTYS: TRYS PRALAIMĖJIMAI}

Tarpukariu Lietuvos spaudoje rašant apie lietuvių tautybès karių patirtis Didžiajame kare, dèmesio centre, galima sakyti, buvo trys Rusijos kariuomenės pralaimèjimai prieš Vokietiją - 1914 m. Rytų Prūsijoje, 1915 m. Augustavo miškuose ir Kauno tvirtoveje. Tai lèmé geografinis aspektas ir lietuvių karių gausa šiose karinèse operacijose, tarnaujant Rusijos arba Vokietijos imperijų kariuomenèse.

1914 m. Jonas Žadeikis buvo mobilizuotas ị 111-ąji Dono pėstininkų pulką, o $1921 \mathrm{~m}$. jau minètoje jo brolio kanauninko Pranciškaus Žadeikio išleistoje knygoje pateikti Jono prisiminimai: „Traukiau tat i karą. Mano širdis valandomis kaito, valandomis šalo. Retkarčiais užeidavo ir pasidrąsinimo mintis: „Štai tu - didvyris, už tèvynę mirsi!“ Bet reikejjo pergalèti ir kitokias mintis, kurios traukte traukè atgal: „Už ką tu nujau eini kariauti? Gal manai už Lietuvą? Tai ne <...>“. Greitai Jonas Žadeikis su savo pulku išvyko ị frontą ir po poros dienų dalinys pakilo ị mūši savųjų paremti. Tačiau ataka baigèsi tragiškai, dalyvio teigimu, „kadgi nepaleis vokiečiai iš kulkosvaidžių ir šautuvų i mus pyškinti - kaip žolè krinta nuo dalgio, taip krito kareivių eilès“. Pažymètina, kad mūšių Rytų Prūsijoje metu, rugpjūčio 19-20 d., 111-asis Dono pėstininkų pulkas neteko apie dviejų trečdalių savo karių (34 karininkų ir 2150 kareivių, dauguma mobilizuoti lietuviškose Rusijos imperijos gubernijose). Tai buvo tik vienas pulkų, dalyvavusių $1914 \mathrm{~m}$. 
mūšiuose Rytų Prūsijoje, kai Vokietijos pajègos sutriuškino 1-ąją ir 2-ąją Rusijos armijas. J. Žadeikis buvo sužeistas ir pateko ị nelaisvę, o po kelių dienų išlaisvintas ir išgabentas ị Maskvą gydytis [261, 10-29]. Apie 1914 m. karinius veiksmus Rytų Prūsijoje vẻliau rašyta: „mums lietuviams svarbu tuos veiksmus patyrinèti“, nes „didelè jų dalis vyko vietose (Mažojoj Lietuvoj), kur seniau gyveno ir dabar tebegyvena lietuvių gentis. Antra vertus, turima prisiminti, kad, mūsų tautos tragedijos dèka, daug abiejų kovojusių pusių kariuomenès dalių, ypač rusų kariuomenès dalių, kurios pirmosios ịsivèlè ir lèmé šias kautynes, iš pradžių daugiausia arba beveik ištisai buvo sudarytos iš mobilizuotų lietuvių atsarginių karių, patyrusių pirmuosius karo smūgius" [260, 1].

Augustavo miškai ir Didžiojo karo patirtis sieti ne tik dèl 1915 m., bet ir dèl nepriklausomybès kovų [137]. Viena vertus, Augustavo apylinkèse (miškų masyve į rytus nuo Augustavo) $1915 \mathrm{~m}$. vasario mèn. Vokietijos karinių pajėgų buvo apsuptas ir sunaikintas 20-asis Rusijos kariuomenès korpusas, kuriame tarnavo daug lietuvių. Kita vertus, 1920 m. rugsejjo mèn. tame pačiame rajone vyko intensyvios Lietuvos ir Lenkijos pajègų kovos, pasibaigusios Seinų-Druskininkų katastrofa [123, 306-330], kai žuvo arba į nelaisvę pateko per du tūkstančius Lietuvos karių, buvo prarastos strategiškai svarbios pozicijos (9) ir kartu Suvalkų kraštas. Taigi Augustavas buvo gana ryškus elementas nepriklausomybès kovų naratyve (10). Vienas iš 1937 m. Vytauto Didžiojo karo muziejuje ịrengtų 35 varpų buvo pavadintas Seinai-Augustavas [117]. Apie 1915 m. Augustavo mūši [57; 194, 89-94] tarpukariu Lietuvoje rašyta: „mums lietuviams, ši kova tuo yra įdomi, kad joje dalyvavo didelis skaičius lietuvių, tarnavusių rusų armijoj“. Karinès operacijos metu Vokietijos pajègos apsupo Rusijos kariuomenès 20-ąj korpusą, kuris buvo mobilizuotas Vilniaus karinėje apygardoje, tad suprantama, kad jame buvo gausu lietuvių. Pasak P. Rusecko, „beveik visi pirmosios mobilizacijos lietuviai pateko ị tą korpusą“, o kai kurios jo kuopos „susidejo maždaug per pusę iš lietuvių“ [208]. Teigta, kad jų buvo keli tūkstančiai, ir nemaža dalis žuvo Augustavo miškuose. Minèto korpuso 113-ajame pulke tarnavęs Mykolas Volodka prisiminè, kad jo kuopoje buvo 28 lietuviai; tai buvo vienas iš dviejų pulkų, kurie prasiveržè iš apsupties. Liudininko teigimu, po kariuomenès puolimo kuopoje liko tik trys lietuviai, kiti žuvo arba buvo sužeisti, o jis pats neteko kojos [145]. Vokietijos žiniasklaida po operacijos paskelbè: „20-ojo korpuso garbė buvo išgelbèta kaina 7000 karių, kritusių vieną dieną per kautynes 2 kilometrų plote. Jie žuvo garbingai! Mèginimas prasilaužti buvo beprotybè, bet šventa beprotybè - karžygiškumas“ [244, 224].

A. Uspenskis, šios kovos dalyvis, patekęs į Vokietijos nelaisvę, savo knygoje rašė, kad 20-ojo korpuso sudètyje Augustavo miškuose karžygiškai žuvo ir daugelis lietuvių, kadangi 1-osios mobilizacijos kariai buvo skiriami ị šio korpuso dalis. Garsiose Gumbinès kautynèse, kurios išgelbėjo Paryžių, vienas iš ypatingai pasižymėjusių ir labiausiai nukentèjusių dalių buvo 111 Dono pulkas, beveik ištisai sudarytas iš lietuvių. Ne be reikalo 1921 m. prancūzų laikraštis „Petit Pasirien“ (11) pareiškè, kad „Lietuviai nusipelnijo

(9) Siauriausias ruožas (fronto linija) buvo nuo Raigardo iki Nemuno ties Gardinu, t. y. apie $63 \mathrm{~km}$ tiesiąja linija, kurio abu sparnus dengè kliūtys - rytuose Nemuno upè, o vakaruose Vokietijos siena.

(10) „Esu aš tas, kuris kritau už laisvę, // tenai, kur mano pulkas viesulu žygiavo. // Tai mano kaulai, tie, kuriuos išmètytus; // po raistus ir laukus surinkot jūs // ir medžio kryžius jiems pastatèt atminimui. // Rytuose ir pietuos, ties Daugpiliu ir Augustavu, // aš grūmiausi su priešu stipresniu“ [195, 10]. Augustavo miškai tapo nepriklausomybès kovų veiksmo vieta romanuose [33].

(11) Ši citata iš A. Uspenskio knygos naudojama plačiau: „1921 m. prancūzų laikraštis Petit Parisien rašè: „... Lietuviai nusipelnè Antantès dèmesio tuo, kad jie pirmieji, gelbėdami Prancūziją, garbingose kautynèse ties Gumbine išliejo savo kraują..." [184]. 
Antantès dèmesị tuo, kad jie pirmutiniai, gelbẻdami Prancūziją garbingai kautynèse ties Gumbine, išliejo savo kraują" [244, 226].

Kauno tvirtovès užèmimas taip pat sulaukdavo kiek daugiau dėmesio. Kariuomenèje buvo skaitomos paskaitos „Kauno tvirtovès žlugimas“ [56]. Tvirtovès užėmimas analizuotas karineje literatūroje $[29 ; 108 ; 135 ; 176]$, o jos šturmas buvo svarbus ir tuo, kad, kaip teigta, „daugiausia lietuvių karių [tarnavusių Vokietijos kariuomenèje - V. J.] žuvo puolant Kauno tvirtovę" [92]. Spaudoje akcentuota, kad Vokietijos kariuomenès gretose žuvo tūkstančiai lietuvių visuose frontuose, o šturmuojant Kauną iš 700 žuvusių vokiečių nemaža dalis buvo lietuviai [191]. Tokị susidomèjimą lėmé trys priežastys: 1) buvo svarbu analizuoti karo veiksmus, vykusius su tomis kitų šalių kariuomenèmis, kurios eventualiai galëjo tapti Lietuvos priešais tame pačiame karo veiksmų geografiniame areale; 2) šie veiksmai vyko Lietuvos arba lietuviškose (tarpukario samprata) teritorijose ir 3) tose kovose iš abiejų pusių dalyvavo tam tikras, tarpukariu įvardytas - didelis, lietuvių kilmès karių skaičius.

\section{DIDYSIS KARAS LIETUVOJE: NUOSTOLIAI, KANČIOS, DEKADANSAS IR LAISVE்}

Didžiojo karo pradžios ir pabaigos sukakčių proga Lietuvos spaudoje pasirodydavo įvairaus pobūdžio straipsniai $[1 ; 42 ; 43 ; 49 ; 50 ; 51 ; 69 ; 97 ; 106 ; 141 ; 142 ; 158 ; 197 ; 224 ; 228$; 237; 264], kuriuose buvo aptariami ịvairūs šio karo aspektai [3, 1269; 151, 2-3]. Antai dvidešimtąją sukaktị savo puslapiuose bene plačiausiai pažymejo periodinis leidinys Kultūra, šiai temai buvo skirta dalis 6-7 numerio [149]; kiek plačiau apie tai tuo metu rašè ir Rytas [177; 178; 179] bei Lietuvos Žinios [170; 180; 181; 188; 236]. Pastarųjų rugpjūčio $1 \mathrm{~d}$. numeryje skelbta: „šiandien sukanka lygiai dvidešimt metų nuo tos atmintinos dienos, kai prasidejo pasaulio istorijoje neregètos skerdynès, vadinamos „didžiuoju Europos karu“ [4]. Tarpukariu spaudoje kiek plačiau analizuotos šio karo priežastys [20; 64; 210]. Istorikas Zenonas Ivinskis Didžiojo karo pradžios 20-mečio proga konstatavo, kad nors prirašyta daugybẻ tomų knygų analizuojant šio karo priežastis, aiškiau netapo, nes skirtingos šalys visiškai priešingai interpretavo faktus. Savo ịžvalgas jis baigè prancūzų mokslininko Gustave’o Le Bono mintimi, kad „’̣ sklidiną taurę vandens Vokietija metè paskutinị lašą, ir vanduo išsiliejo. Bet klausimo esmẻ labiau glūdi tame, kas pripilde tą stiklą, o ne tame, kas metė paskutinị lemiantị lašą " [73]. Ta pačia proga Lietuvos aidas publikavo Paneuropos judejimo pradininko Richardo Nikolaus Coudenhove-Kalergio straipsnị, kuriame autorius rašè, kad „mes einame skubiu žingsniu arba ị Europos karą, arba ị Europos Valstybių Sąungą“, nes be tokios organizacijos, jo nuomone, ir ateityje karas Europoje neišvengiamas [42].

Lietuvoje tarpukariu Didžiajam karui teiktas dèmesys ne tik sukakčių proga, bet ir kituose kontekstuose. Paminėtinos gen. Leono Radus-Zenkavičiaus, plk. Jono Petruičio ir Justo Paleckio knygos $[164 ; 176 ; 194]$, skirtos Didžiojo karo istorijai. Kaipgi buvo vertinama šio karo reikšmė Lietuvai?

Pirmojo pasaulinio karo metu Lietuvos teritorija stipriai nukentejo, ne vienas miestas patyrè milžiniško masto sugriovimus. Kalvarija, Kybartai, Šakiai, Tauragė ar Šiauliai buvo virtę griuvėsių krūvomis. Tuoj po karo Lietuvai padaryti nuostoliai (teritorijoje be Vilniaus krašto), ekonomisto Albino Rimkos skaičiavimu, buvo įvertinti 3,733 mlrd. Lt (12) (pagal tarpukario lito ir aukso paritetą suma lygi 561,677 tonoms aukso). Palyginkime: per

(12) Ekonomisto skaičiavimais, vokiečių padaryta žala buvo lygi $2,917 \mathrm{mlrd}$. Lt, o rusų - $816 \mathrm{mln}$. Lt; čia autorius ịskaičiavo ir bermontininkų bei bolševikų padarytą žalą [203, 319]. 
16 m. (1924-1939 m.) Lietuvos biudžeto išlaidos siekė 4,539 mlrd. Lt. Per karą Šiauliuose buvo sugriauta ar apgriauta 1900 pastatų, Tauragèje - 410, Raseiniuose - 100, Panevéžyje - 100, Kybartuose - 100, Naumiestyje - 100, Pabradejje - 100, Kaune - 50 pastatų [182, apv. 1. 4] 1919 m., palyginti su laikotarpiu prieš Didijji karą, arklių sumažèjo $38 \%$, galvijų - 47,7 \%, kiaulių - 44 \%, avių - 30 \%. 1918 m. dirvonavo 35 \%, o 1919 m. - 16,4 \% laukų. Karo metu sudegè 1200 sodžių su 14270 ūkių, 2000 vienkiemių, 270 dvarų ir 50 miestelių, iš viso 57080 pastatų [107, 399]. 1916 m. lietuvių kalba JAV išleistoje knygoje kunigas Vincas Bartuška, sugrịžęs iš kelionès po Lietuvą, rašè apie sugriautą žemès ūkį: „Pilviškių miestelio šiapus Pilvès ir Šešupès nieko neliko. Anoj gi pusèj išdeginta klebonija, bet bažnyčia nelytėta. Pravažiavus Pilviškių miestelį, akysna keliauninko puola baisus reginys. Kur-ne-kur rioglinejja karvutè-našlelè, arba per tuščius laukelius kiutina susirietęs lietuvis-žmogelis. Rodos užklaustum karvutès kur dingo jos skaitlingos sesutès, ir žmogaus ar neliūdna ir nebaugu jam vienam vaikščioti po plačius laukus ir išnaikintas sodybas" [22, 39-40]. 1937 m. išleistoje knygoje V. Bartuška pakartojo savo 1916 m. kelionès iš JAV i Lietuvą ịspūdžius [23, 47-48]. 1925 m. Trimite rašyta, kad karo metu sugriauti Seredžius [115] ir Šeduva [116] jau buvo beveik atstatyti. Apie Baisogalą 1928 m. rašoma: „Didysis karas paliko čia pėdsakų - trečdalis išdegusio miestelio, pamatai, kurie ir dabar tūnoja, apdaužyta artilerijos sviediniais bažnyčia ir dideli brolių kapai. Čia būta nemažų kovų. Miestelis kelis kartus buvo perejjęs tai vokiečiams tai rusams" [16]. 1929 m. konstatuota, kad „po didžiojo ir Nepriklausomybès karo audrų esame išvargę, ūkis reikalauja daugelio metų, kol atsistatys" [9]; kartu agituojama skatinti JAV lietuvių sugrị̌zimą i Lietuvą su taip trūkstamu kapitalu investicijoms.

Kitas sąsajų su Didžiuoju karu aspektas tarpukariu buvo moralès ir vertybių dekadansas. „Atūžusi Didžiojo karo audra“ esą viską nušlavè, gyvenimas pakrypo „kitomis vèžèmis“ [40, 874], o karas ir Vokietijos okupacija „pakirto lietuvio fizines ir dvasines jègas“ $[239,500]$. Trimite Rusijos okupacijos ir „Didžiojo karo neigiamu palikimu“ įvardyta apsileidimas, tarpusavio nesantaika, girtavimas ir kiti neigiami reiškiniai, kurie ardè lietuvių tautinę vienybę, trikdè darbą [46, 131]. Anot Antano Smetonos, prasidejjus karui, dorovès désnius, kuriais rèmèsi visuomenè, pakeitė žiaurumai, o „Lietuva pirma tapo karo auka“ $[249,957]$. Rašyta, kad po Didžiojo karo pakriko tikèjimas sąžine, įsigalèjo nejaukus sumaterialèjimas, išplito nusikalstamumas [77]. „Praūžusi didžiojo karo audra ị šeimų gyvenimą ịnešè didelę ir sunkiai atitaisomą disharmoniją, pakrikimą, šeimų išsiblaškymą“ [147], todèl po Didžiojo karo „pakrypo, šeimos pamatai“ ir padaugèjo skyrybų [76]. Apskritai „Didysis karas apnešè visą pasauli moralès puvėsių dulkėmis. Ir tos dulkès kaskart vis giliau skverbiasi [i]] visų tautų“, įskaitant ir lietuvius, širdis [230, 352]. 1934 m. Trimite pažymèta, kad „Prieš didijj karą visuomeninis gyvenimas ir jo tempas buvo visai kitoks negu“ po karo. Anksčiau buvo „nusistovèjusi ir palyginti rami visuomenès būtis“, o karas pagimdè ekonominę ir dvasinę krizę, kuriai ịveikti reikejjo „stambių socialinių ir vidaus politikos reformų" $[63,351]$.

Bendras vaizdas iliustruotas tokiais teiginiais: „Didžiojo karo metu Lietuvoje buvo ypatingai sunkios sąlygos vaikams auginti, jų ne tik mažiau gimé, bet didesnis, negu paprastai, nuošimtis mirë“ [114]. 1925 m. nuogąstauta, kad tautai gresia sergamumo sifiliu proveržis, nes net nedidelèje kaimiškoje teritorijoje buvo nustatyta 200 minètos ligos atvejų. Teigta, kad sifilis Lietuvoje paplito Didžiojo karo metu, o „liga užnešta rusų ir vokiečių kariuomenių“, nes prieš karą apie tokią ligą esą beveik nebuvo girdèta, susirgimų pasitaikydavo tik miestuose. Tačiau po karo jau ir kaimuose sirgo ištisos šeimos [233, 
193]. Taigi karo negandos buvusią „sveiką lietuvių tautą“ užkrète ịvairiomis venerinėmis ligomis. Konstatuota, kad Lietuvoje neliko valsčiaus, kuriame nebūtų išplitusi ši liga, o pagal oficialią statistiką, sergančiųjų tuo metu buvo per 10 tūkst. [238, 756]. Taip pat rašyta, kad daug žmonių mirdavo nuo džiovos, nes po Didžiojo karo pablogèjo gyvenimo sąlygos [248, 52].

Analizuojant tarpukariu paskelbtas publikacijas apie Didiji karą Lietuvoje, akivaizdu, kad jis buvo vertinamas ne tik dèl sugriovimų, aukų ar venerinių ligų, bet ir atsivèrusios galimybès atkurti nepriklausomybę. Antai 1925 m. rašyta: „pasaulinio karo dèka, Lietuva vèl pabaigè vergų dienas ir $\langle\ldots\rangle$ varo savo naują nepriklausomo gyvenimo vagą “ $[91,2]$. Spaudoje ịvardijama Didžiojo karo reikšmė atkuriant valstybingumą: „Daugeliui valstybių laisvę davè didysis karas“ [5, 489], „didysis karas išvadavo atskiras tautas iš vergijos“ (taip Kompjeno paliaubų proga rašè būsimasis generolas S. Raštikis [197, 766]). Vaclovo Sidzikausko teigimu, „Didžiojo karo padariniai pagreitino tautinio atgimimo vyksmą ir sudarè palankesnes sąlygas išsilaisvinti“ $[263,56]$, - diplomatas ir teisininkas taip ịvertino karo reikšmę Mažosios Lietuvos „susijungimui“ su Didžiąja Lietuva. Pabrėžta, jog „praūžusiame Didžiojo karo ir revoliucijų košmare iškilo tautų apsisprendimo teisè“ $[223,8]$. Minint nepriklausomybès 10-metị pažymèta, kad „Didysis karas sutraukè caro Rusijos uždètus Lietuvai pančius“ $[244,216]$. Pagaliau karas suvoktas ir kaip bausmė imperijoms, pavergusioms mažąsias tautas: esą „tik didysis karas nubaudè tuos, kurie ją slègè, ir apdovanojo laisve slègtuosius jos sūnus" [94].

Spaudoje buvo pripažįstamas karo kaip griaunančios ir kartu sudarančios sąlygas kurti stichijos vaidmuo, ji prilyginant nevaldomam ir dažnai netikètam gamtos reiškiniui - audrai. Lietuvos šaulių sąjungos vado plk. Prano Saladžiaus teigimu, „atūžusi Didžiojo karo audra labai sukrètė mūsų tautą, kai suliepsnojo lietuviškosios sodybos. Lietuvis dar labiau susirūpino savo tautos likimu“ $[125,50]$; „tačiau didelių suiručių metu ir mūsų tèvynė Lietuva išsikovojo (13) sau nepriklausomybę“ [98, 13]. Praejjus dvidešimčiai metų nuo karo pradžios literatūros kritikas Vytautas Pranas Bičiūnas, analizuodamas Maironio, mirusio prieš dvejus metus, kūrybą, taikliai pažymèjo, kad „Lietuvos laisvès grị̌imas ir susikūrimas Lietuvos valstybès iš likusių po didžiojo karo griuvèsių panašus ị stebuklą" [25, 513]. Generalinio štabo plk. ltn. Kazys Grinius, buvusio Prezidento sūnus, rašè, kad „lietuvių aukos - vis tiek kurioje stovykloje jos bebūtų - nebuvo bergždžios. Tik abiem imperijoms žlugus, Nepriklausomos Lietuvos atstatymas virto galimas“ $[66,112]$. O Tautos mokykla svarstė, ar ne per didelès buvo milijoninès aukos, kad „lietuvių, lenkų, prancūzų, čekų, slovakų, serbų, rumunų“ ir daugelis kitų aukų išsilaisvintų? Pabrèžta, kad i tai sunku atsakyti, nes „laisvè ir mirtis abi metafizinès vertybès, kilogramais nepasveriamos ir pinigais neikainojamos" [99].

1937 m. Respublikos Prezidentas Antanas Smetona, sveikindamas lietuvius karius, 1917 m. Rusijoje susibūrusius ị tautinius dalinius, pabrèžè: „reiškiame giliausios pagarbos tiems jų draugams, kurie paaukojo savo gyvybę Lietuvai, būdami lietuvių karių eilèse, svetimoje arba savo šalyje. Garbè ir meilè tèvynès gynejjams!“ [47]. 1938 m. Sofija Smetonienè, kalbėdama per Kauno radiją, teigé, kad „Didysis karas ne per seniai pasibaigè. Ir aš ir Jūs daugumas gerai atsimenate visas jo baisenybes. Bet karas praejo ir kraujo aukos dètos ant Tẻvynès aukuro veltui nežuvo. Mūs brangioji Lietuva nusikratè vergovès pančius ir įejjo lygiateisiu nariu ị kitų nepriklausomų valstybių tarpą“ [221]. Didžiojo karo

(13) Kitur vartojamas ir atgavimo terminas: „tauta pergyveno visas didžiojo karo baisybes ir krauju atgavo savo nepriklausomybę" $[247,239]$. 
metu žuvusių lietuvių karių aukos ịvardytos kaip „atnašas ant laisvės aukuro“ $[31,14]$. 1939 m. išleistos knygos apie Pirmąji pasaulinị karą izžangoje Petras Ruseckas teigè, esą Didysis karas Lietuvoje buvo vienas baisiausių ịvykių istorijoje, kuris suvienijo lietuvių tautą ir ji „organizavosi, ruošèsi i̇ galutiną, žūtbūtinę kovą dèl Nepriklausomybès atgavimo“ [išskirta - V. J.] [124, 3-5]. Galiausiai prieita išvada, kad „šiaip, ar taip mūsų šalis, kaip ir kitų mažųų tautų atsivadavo Didžiojo Karo metu ir mums Didysis Karas visuomet bus labiau minètinas įvykis, kaip kam kitam“ [228].

Taigi Didysis karas tarpukariu Lietuvoje vaizduotas kaip tautos kančių, ūkio nuosmukio, milžiniškų materialių nuostolių ir patirtų aukų laikotarpis. Dẻl jo smuko žmonių moralè, pakriko tradicinès vertybès, krašte paplito ịvairūs susirgimai, ypač venerinès ligos, kurios tarsi patvirtino tą dorovès nuosmukį. Tačiau, be viso to, karas ịvardytas ir esminiu, lūžio įvykiu, atvèrusiu kelią Lietuvos nepriklausomybei, o Didžiojo karo aukos buvo suvokiamos kaip aukos ant nepriklausomybės aukuro.

\section{DIDŽIOJO KARO ATMINIMO PRAKTIKOS EPIZODAI TARPUKARIO LIETUVOJE}

Kaip Didžiojo karo atminimas Lietuvoje buvo pasitelkiamas politiniams tikslams, iliustruoja ir valstybingumo dešimtmečio minejjimo pavyzdys. Tuo metu Lietuvos užsienio politika buvo orientuota ị Vokietiją, abiejų šalių kariuomenès palaikè draugiškus santykius (14). 1928 m. gegužès 15 d. Vokietijos karinė delegacija (15) dalyvavo Laisvès paminklo Karo muziejaus sodelyje atidengimo ceremonijoje ir padejo vainiką (spaudoje pažymėta, kad tokius vainikus Vokietijoje deda ant Didžiojo karo aukų kapų). Kitą dieną i vokiečių karių kapines Kaune atvyko Karininkų ramovės atstovai, Vokietijos atstovas Hansas Morathas su žmona ir atstovybès valdininkai, Vokietijos karininkų delegacija ir kt. [80]. „Gegužès 16 d. 9.30 val. prie vokiečių kapinių vartų buvo pastatyti špaleriai (16) gusarų su plikais kardais." Lietuvos kariuomenès husarų pulko orkestras atliko Ludwigo van Beethoveno gedulingą maršą, Vokietijos ir Lietuvos himnus. Ant paminklo per Didiji karą žuvusiems Vokietijos kariams vainiką nuo Karininkų ramovés tarybos padejo gen. ltn. V. Nagevičius, o nuo Vokietijos kariuomenès - gen. št. plk. O. C. E. Schroederis. Delegacija buvo priimta aukščiausiu lygiu, lankèsi pas Respublikos Prezidentą, Karo muziejuje, kariniuose daliniuose [255, 420]. Panašūs Didžiojo karo aukų pagerbimo ritualai Lietuvoje vyko ir po dešimtmečio, tačiau jau prancūziškos trispalvès fone.

Tarpukariu Lietuvos kariuomenè orientavosi ị Prancūzijos karo mokyklą, įdèmiai sekè karybos inovacijas šioje šalyje, savo karininkus siuntė studijuoti beveik vien $\mathfrak{i}$ Prancūziją ar jos karo mokyklos įtakoje buvusias šalis - Belgiją ir Čekoslovakiją. Be to, Prancūzijoje pirkta nemažai ginkluotès [plačiau žr. 85]. Apskritai Prancūzijos diplomatai palaikè puikius santykius su gen. Silvestru Žukausku, kurị apibūdino kaip „frankofilą“, panašiai vertino gen. Teodorą Daukantą - kaip „vieną iš labiausiai mums [Prancūzijai V. J.] atsidavusių lietuvių“ [36, 269]. 1937 m. Prancūzija Lietuvos kariuomenès bibliotekai padovanojo 160 tomų ịvairių knygų karo mokslų (sąraše 103 pavadinimų knygos), istorijos, tarptautinès teisès, veterinarijos ir t. t. temomis [216] prancūzų kalba, kurių vertè

(14) Lietuvos ir Vokietijos kariuomenès draugiškus santykius palaikè iki 1933 m. imtinai, plačiau žr. [85, 54-61].

(15) Reichsvero 10-ojo pėstininkų pulko vadas gen. št. plk. Otto Carlas Eduardas Schroederis (Šrederis), 1919 m. tarnavęs Lietuvos kariuomenejje, jo adjutantas vyr. ltn. Heigendorfas, gen. št. mjr. Ditmeringas, gen. št. kpt. Almendingeris [255, 419].

(16) Špaleriai - kariuomenès eilès iš abiejų kelio pusių juo vykstančiam asmeniui pagerbti. 
buvo 6500 Prancūzijos frankų [186]. Taigi Lietuvos karininkija buvo persismelkusi prancūziška dvasia. Darytina prielaida, kad tam, viena vertus, turèjo ịtakos tai, kad Lietuvos kariuomenę kūrè buvę Rusijos imperijos karininkai, Didžiojo karo dalyviai, kovoję Antantès pusejje. Kita vertus, racionalu sekti nugalètojų (tarpukariu tai buvo Antantès šalys), o ne pralaimètojų pavyzdžiu.

Prancūzija per savo diplomatinę atstovybę ir Lietuvių-prancūzų draugiją, jos kultūrinę veiklą stengèsi daryti politinę ịtaką Lietuvoje [173; 174; 175]. Draugija, kuriai 1937 m. priklausė apie 250 narių, buvo ịkurta 1923 m., jos valdybos pirmininkais buvo Jonas Vileišis, Edvardas Turauskas, Mykolas Römeris [2]. XX a. 4-ajame dešimtmetyje, blogejjant Lietuvos ir Vokietijos santykiams, suintensyvèjo Lietuvos kultūrinè orientacija ì Prancūziją, vokiečių kalbą gimnazijose išstūmè prancūzų kalba, kurią dažnai dèstè prancūzai, ir tai neabejotinai davė rezultatų [120, 97]. 1936 m. lietuviškoje spaudoje skelbta, kad Prancūzijos dienraštyje Matin buvo publikuotas straipsnis apie Lietuvos politiką ir ekonomiką, kuriame pabrèžta, kad „Lietuva vis labiau ir labiau prisiartinanti prie Prancūzijos. Tuo reikalu viešoji Lietuvos nuomonè visiškai pasikeitusi per paskutinius kelerius metus. Tam esą geriausias ịrodymas tas, kad Lietuvos gimnazijose vietoje vokiečių kalbos buvusi ịvesta prancūzų kalba“ [140]. Taip buvo iggyvendinama minkštosios galios politika - Lietuvos visuomenèje formuojama tam tikra "frankofilų“ terpé, per kurią būtų galima daryti ịtaką. $1936 \mathrm{~m}$. birželio $4 \mathrm{~d}$. ị draugijos valdybą buvo išrinkti prof. M. Römeris, Marija Urbšienè, Marija Smetonaitė-Valušienè, plk. Pranas Lesauskas, Pranas Viktoras Raulinaitis, Paul Neyracas, R. Schmittleinas ir Bačkis [126]. M. Smetonaitè-Valiušienè ir M. Urbšienè, t. y. Prezidento dukra ir Užsienio reikalų ministro (17) žmona, į valdybą buvo renkamos ir vèlesniais metais [129]. 1939 m. Respublikos Prezidento dukra M. Smetonaitė-Valušienè, Lietuvių-prancūzų draugijos vicepirmininkè, buvo apdovanota Prancūzijos garbès legiono V laipsnio kryžiumi už lietuvių ir prancūzų kultūrinio suartinimo veiklą [10;250]. Prancūzijos apdovanojimus gavo ir kiti aktyvūs draugijos nariai [185].

1934 m. Lietuvių-prancūzų draugija kreipèsi į Valstybinès konservatorijos direktorių, kad šis suteiktų nemokamai salę lapkričio $11 \mathrm{~d}$. „prancūzų dainos ir muzikos“ koncertui su paskaita, taip siekiant „lietuvių-prancūzų kultūrinio susiartinimo“ [128]. 1935 m. lapkričio 22 d. draugijos posėdyje buvo nutarta 1936 m. gegužès mẻn. surengti „prancūzų žuvusiųjų karių Didž. kare“ minèjimą [190]. 1936 m. lapkričio 11 d. Lietuvių-prancūzų draugija organizavo pamaldas studentų (Švč. Sakramento) bažnyčioje „karo paliaubų dienos proga“. Šv. Mišias laikè kanauninkas prof. Blažiejus Čèsnys, patarnavo karo invalidas. Pamaldose buvo Prancūzijos pasiuntinys Kaune Georges’as Ferdinandas Charles'as Dulongas, pasiuntinybės sekretorius P. Neyracas, atašė Grandclementas, Lietuvos kariuomenès husarų pulko vadas gen. št. plk. Aloyzas Valušis, prof. R. Schmittleinas su žmona, advokatas P. V. Raulinaitis ir kt. [166].

1937 m. Lietuvių-prancūzų draugija, minėdama „Napoleono jubiliejinius metus“ (125-osios žygio ị Rusiją metinès; šiam ịvykiui paminèti Lietuvos kariuomenè skyrè išskirtinị dėmesị, o Vytauto Didžiojo karo muziejuje gen. V. Nagevičius iniciatyva buvo įrengta speciali šiam kariniam žygiui skirta ekspozicija [127; 154]), lapkričio $11 \mathrm{~d}$., Didžiojo karo paliaubų dieną, surengè minėjimą „mirusių lietuvių ir prancūzų karių 1812 m. Napoleono žygyje per Lietuvą i Rytus, o taip pat žuvusių kovos lauke per Didijj

(17) Juozas Urbšys nuo 1934 m. - URM Politikos departamento direktorius Kaune, nuo 1936 m. - URM generalinis direktorius, o 1938 m. paskirtas užsienio reikalų ministru. 
karą 1914-1918 m. “ pagerbimui. Studentų bažnyčioje laikytos šv. Mišios, o prie Karo muziejaus nuleidžiant vèliavą buvo padètas gyvų gèlių vainikas. Kalbejjo Lietuvių-prancūzų draugijos pirmininkas P. V. Raulinaitis ir Prancūzijos atstovas G. F. C. Dulongas. I šia proga surengtą prièmimą atvyko Prancūzijos atstovas G. F. C. Dulongas su žmona, gen. št. plk. Jonas Černius, brg. gen. Vladas Nagevičius, brg. gen. Kazys Tallat-Kelpša, plk. inž. Antanas Gustaitis, gen. št. plk. ltn. A. Valušis, prof. Zigmas Žemaitis, kiti aukšti karininkai bei visuomenès atstovai [153].

1938 m. draugijos veiklos ataskaitoje teigta, kad ji ,jautri ịvykiams, kurie labiau liesdavo lietuvių ir prancūzų tautų gyvenimą. Taip [1937 m.] lapkričio 11 d. Valdybos rūpesčiu buvo suruoštas paminèjimas žuvusių lietuvių karių 1812 metais Napoleono žygyje per Lietuvą ir Didžiajame kare. Tam tikslui buvo suruoštos pamaldos ir popiet Karo Muziejuje buvo iškilmingai paminèta ta diena“ [131]. 1938 m. P. V. Raulinaitis spaudoje rašè, kad „abiejų tautų draugingumas yra pašventintas tūkstančiais jaunųjų karžygių gyvybių abiejų tautų laukuose. Mūsų žemè priglobẻ tūkstančius 1812 m. žygio dalyvių palaikų, o 1914-1918 m. kare prancūzų laukuose ilsisi nemažai lietuvių karių savanorių iš Jungtinių Amerikos Valstijų ir kitų kraštų. Nereikia daug aiškinti kaip šiedvi tautos yra giminingai surištos“ " [198].

Kad Didžiojo karo atminimui skirti renginiai XX a. 4-ajame dešimtmetyje buvo susiję su Lietuvos politika Prancūzijos atžvilgiu, iliustruoja 1938 m. Lietuvos aido publikacija apie Didžiojo karo pabaigos 20-mečio minejjimą Kaune. Laikraštyje buvo skelbiama apie vyksiančius renginius: „šiandien, lapkričio 11 d., Prancūzijai minint dvidešimties metų pasaulinio karo paliaubų sukaktị, Lietuvių Prancūzų Draugija ir Kaune ruošia atitinkamą minèjimą“. Taigi minèjimas pirmiausia rengtas todèl, kad ši sukaktis buvo svarbi Prancūzijai, ir tai yra aiški politinès orientacijos išraiška. Lietuvos kariuomenès vyriausiasis kapelionas Adolfas Sabaliauskas 8.00 val. turejjo laikyti šv. Mišias už „Didžiajame kare žuvusius lietuvius ir prancūzus karius" [235]. Draugija kvietė savo narius ir Prancūzijos bičiulius „gausingiausiai dalyvauti“ renginiuose. Po pietų Didžiojo karo paliaubų 20-mečio minèjimas Kaune persikèlè prie Nežinomojo kareivio kapo Karo muziejaus sodelyje [132]. Lapkričio 11 d. Igulos bažnyčioje šv. Mišiose A. Sabaliauskui asistavo Didžiojo karo dalyvis tėvas dominikonas Pelletier. Karo muziejaus sodelyje per vèliavos nuleidimo apeigas Prancūzijos igaliotas ministras G. F. C. Dulongas su tèvu dominikonu Pelletier padejo ant Nežinomojo kario kapo gyvų gèlių vainiką, perrištą Prancūzijos ir Lietuvos tautinių spalvų kaspinais, taip pagerbdami Didžiajame kare žuvusius lietuvių ir prancūzų karius. Kalbas pasakè Prancūzijos ịgaliotas ministras G. F. C. Dulongas, lietuvių-prancūzų draugijos pirmininkas P. V. Raulinaitis ir brg. gen. Vladas Nagevičius, kuris atstovavo kariuomenès vadui brg. gen. S. Raštiniui. Po iškilmių brg. gen. V. Nagevičius pakvietė svečius apžiūrèti Karo muziejų [163].

Konstatuotina, kad 1938 m. lapkričio 11 d. iškilmès prie Nežinomojo kareivio kapo Didžiojo karo paliaubų sukakčiai paminèti „buvo suruoštos Prancūzijos pasiuntinybės“, jose draugijos nariai dalyvavo „laisvu noru“ [196]. 1939 m. lapkričio 11 d. „buvo paminèta, kaip jau iprasta tradicija reikalauja lapkričio mėn. $11 \mathrm{~d}$. pamaldomis už garbingai žuvusius Didžiajame kare lietuvius ir prancūzus karius" [130]. Apie tai 1939 m. lapkričio 10 d. spaudoje buvo išplatintas skelbimas, kad „pagal savo tradiciją, Lietuvių-Prancūzų Draugija šiemet, kaip ir kitais metais, ruošia ši šeštadienị lapkričio 8 val. ryto Studentų bažnyčioje (Vilniaus g. 2) pamaldas už lietuvius ir prancūzus žuvusius 1914-1918 metų kare. Prašome visus, kad galès, tose pamaldose dalyvauti“ [167; 168]. Taigi buvo tęsiama Didžiojo karo aukų (prancūzų ir lietuvių) pagerbimo tradicija. 
1939 m. kino teatras „Forum“ Kaune pradejo rodyti prancūzų filmą „Marnos didvyriai“ (pranc. „Le Héros de la Marne“, 1938 m. (18), režisierius André Hugon), reklamoje buvo rašoma, kad 1914 m. yra „kruvinos tautų tragedijos pradžia“ [187]. Tarpukariu rodomi filmai buvo prižiūrimi cenzūros, išskirtinị dèmesị kinui skyrè kariuomenė, laikydamasi pozicijos, kad „kinas šiuo moderniuoju metu yra didelis kultūrinimo bei auklejimo veiksnys" $[78,1059]$. Taigi filmas apie prancūzų tautos pasiaukojimą kovojant prieš vokiečius 1914 m., Lietuvoje 1939 m. pavasarị, ką tik netekus Klaipėdos krašto, turejjo ne tik komercinę bei pramoginę, bet ir gilią politinę potekstę. $1939 \mathrm{~m}$. pavasarị ministras pirmininkas brg. gen. Jonas Černius pokalbio su Lenkijos karo atašè plk. Leonu Mitkiewicziumi metu energingai pasisakẻ už „prevencinị karą“ su Vokietija [133, 27, 342-344].

\section{KARIŲ KAPAI}

Tarpukariu teigta, kad „visos tautos gerbia savo mirusius, juos laidoja gražiausiose vietose, tvarko ir puošia jų kapus. Ypač visi gerbia žuvusius dèl Tẻvynès karius, nes jie atiduoda savo gyvybę dèl visos tautos gerovès. Todèl visos kultūringos valstybès nesigaili lèšų ir triūso kapams tvarkyti“ [81, 27]. 1933 m. V. P. Bičiūnas per Vèlines priminè, kad dažnai „senovès karžygių“ kapuose ilsisi „mūsų senoliai“ - lietuviai kariai, kvietė aplankyti XIX a. sukilimų ir Didžiojo karo bei nepriklausomybės kovų karių kapus [24, 862]. 1935 m. Vèlinių kontekste konstatavus jau susiformavusią tradiciją pagerbti nepriklausomybės kovų metu žuvusius karius, buvo atkreiptas demesys, kad Kauno kapinèse ilsisi trijų kariuomenių kariai - Lietuvos, Vokietijos bei Rusijos, ir pastarųjų kapų niekas nelanko, neuždega žvakių, nededa vainikų, o tarp jų gausu lietuvių kilmės karių. Vokietijos kariuomeneje tarnavusių karių kapai buvo sutvarkyti pavyzdingai, o Rusijos daliniuose tarnavusių - apleisti [192]. 1936 m. Vélinių proga Karyje rašyta, kad Lietuvoje yra daugybė lietuvių karių, žuvusių Didžiojo karo metu, neprižiūrimų kapų (19). Karo invalidai Lietuvoje atkreipè demesį, kad nepriklausomybès kovų aukoms atminti skirta kur kas daugiau dèmesio nei Didžiojo karo, nors, pasak jų, ir pastarieji buvo lietuviai, žuvę už Lietuvą, ant jų kapų atsikūrè valstybè (20). Karių kapai Lietuvoje buvo tvarkomi neišskiriant nei Didžiojo, nei nepriklausomybès kovų aukų. 1939 m. atgavus Vilnių buvo atkreiptas dėmesys, kad Vilniuje, Antakalnyje, yra atskiros apie 18 ha karių kapinès, kuriose palaidoti Lenkijos, Vokietijos ir Rusijos kariai, o tarp pastarųjų buvo „daug lietuviškų pavardžių. Tai per Didịji karą lietuviai, tarnavę rusų kariuomenèje“ [79].

1921 m. siūlyta, kad kariniai daliniai saugotų „žuvusių ir mirusiųjų dalies karių kapų fotografijas, sąrašus ir planus“ $[211,191], 1922$ m. Karyje rašyta, kad Lietuvos

(18) Filmas „Le Héros de la Marne“. [2016 08 11]. Prieiga per internetą: <https://www.youtube.com/watch?v=BBE3jQ52Iso $>$.

(19) „Mūsų krašte yra dar daug lietuvių karių kapų, prie kurių Vẻlinių dieną niekas neatejo, niekas ten neužžiebė žvakučių ir niekas nesimeldè. Tai didžiojo karo laikų kapai, kur yra palaidota tūkstančiai karių. Nemažas skaičius tokių kapų šiandieną apžèlę žolèmis, prie kitų stovi begriūvą mediniai kryžiai, o kiti jau seniai susilygino su žeme ir iki mūsų dienų neišliko jų nẻ pèdsako" [92].

(20) „Kur kova ten ir aukos. Aukų jau turi ir Lietuva, bet tos aukos kažkaip arčiau ir jautriau suprantamos nei anos tik ką praūžusio, Didžiojo karo aukos. Ten žuvęs ar sunkiai sužeistas lietuvės motinos sūnus apverkiamas ir apgailimas kaip nelaimès ištiktas žmogus, o čia laisvės kovų auka jau lygiai ir motinos ir visos šalies buvo, greta gailesčio kartu ir pasididžiavimas savais didvyriais; jiems teikiama ypatinga pagarba, kokią ligi šiol žinojo tik iš pasakų ir raštų, kad nèra didesnio pasiaukojimo kaip mirtis už kitus. Tokių pasiaukojusių sūnų Lietuvai nestigo, ant jų kapų, atsistatė Laisvoji Lietuva“ [31, 14]. 
nepriklausomybės kovų karių kapais nei Kaune, nei provincijoje nesirūpinama, jie apleisti ir žole apžèlę $[32 ; 74 ; 212]$. Panašūs rašiniai spaudoje kartojosi ir vèlesniais metais [6; $11 ; 52 ; 90 ; 93 ; 152 ; 207]$. Buvo teigiama, kad karių kapais Lietuvoje nesirūpinama dèl „nekultūringumo" ir visiško apsileidimo, dvasios bei proto tingejjimo [229]. $1924 \mathrm{~m}$. spaudoje rašyta, kad nepriklausomybės kovų aukų kapai apleisti, palaidojimai buvo pažymėti paprastais, mediniais, net nedažytais kryžiais. Retoriškai klausta: „Ką pamanyti, prisižiūrejjus dailių užrašų ant vokiečių kareivių kapų?" [151]. 1925 m. piktintasi apleistais nepriklausomybès kovų aukų kapais Kèdainiuose (21). Kariuomenejje buvo teigiama, kad karių kapų tvarkymas „užmirštas, bet kartu labai pribrendęs reikalas. Tą reikètų kuo greičiau sutvarkyti, nes kiti mūsų kaimynai, kaip latviai, vokiečiai tą darbą jau yra užbaigę " [105]. 1927 m. konstatuota, kad nepriklausomybès kovų aukų kapai buvo tvarkomi ir paminklai statomi tik ten, kur buvo tų kovų dalyvių arba inteligentijos, o apskritai reikejjo „iš gèdos rausti, muštis ị krūtinę ir sakyti: „nostra maxima culpa“ [266]. Visuomenejje piktintasi ir atvejais, kai Lietuvoje buvo tyčiojamasi iš Rusijos karių kapinių. Štai Betygalos val. Pagrubičių k. ūkininkas žuvusius rusų karius palaidojo po slenksčiu, to paties valsčiaus Dickainių k. ūkininko lauko pakraštyje buvo aptvertos rusų karių kapinès su kryžiumi, žemés savininkas kryžių sukūreno, o lauką suarė [35]. Lietuvoje ne Vokietijos karių kapų tvarkymas platesniu mastu (pirmieji darbai atlikti 1924-1925 m.) (22) pradètas tik 1927 m., kai Karo mokslo valdybos švietimo dalies vedejjo plk. ltn. Romualdo Buroko iniciatyva KAM buvo sudaryta Žuvusiųų ir mirusiųjų karių kapams tvarkyti komisija [82; 83; 96; 101; 111; 119], kuri ir koordinavo darbus. Nuo XX a. 4-ojo dešimtmečio ị karių kapų tvarkymo darbus aktyviai ịsitraukè (23) Lietuvos šaulių sąjunga. Žuvusių karių pagerbimas Lietuvoje, kaip ir kitose Europos valstybėse, buvo politinis veiksmas, rengti ìvairūs, dažnai religinio atspalvio ritualai [plačiau žr. 222].

Visa Lietuva buvo nusèta Didžiojo karo karių kapais. 1919 m. Lietuvoje buvo apie 600 karių palaidojimo vietų $[110,58](24)$. Panevėžyje vietinei valdžiai iškasus ir perlaidojus vokiečių karių kapus (apie 400-600) [241], o Vokietijai ị tai atkreipus demesị, Lietuvos vyriausybès institucijos informavo apskrities valdžią, kad „toksai nutarimas, prieštaraująs žmoniškumui, turi būti kuo greičiausiai atmainytas ir perspèti, kad vienas šiame atvejyje prasižengimas bus baudžiamas“ [257]. Matyt, paskatintas šio precedento VRM Tikybų departamentas 1919 m. rugsèjo 19 d. raštu kreipèsi ị apskričių viršininkus, nurodydamas, kad Vokietijos karinėms pajėgoms išsikrausčius iš Lietuvos, „be jokios globos ir prieglobsčio“ likę Didžiojo karo vokiečių karių kapai turi būti apsaugoti nuo „visokių ardymų“, taip pat prašyta vietos valdžios perimti apskričių ribose buvusių karių kapų priežiūrą [258]. Vokietijos atstovybè savo ruožtu taip pat kreipèsi ị Lietuvos valdžią,

(21) „Teko matyti Kèdainių katalikų kapuose karių kapus. Kariai, kaip kokie nusikaltèliai, <..>. Ar tai nepajuokimas iš mūsų kariuomenès karių? Kiti kapai jau ir kryžių neturi“ [11].

(22) 1924-1925 m. Širvintose susikūręs komitetas iš surinktų lěšų sutvarkẻ karių kapus Širvintose, Šešuoliuose ir Musninkuose, tais pačiais metais 8-ojo péstininkų pulko kariai ir skautai tvarkẻ karių kapus Šiaulių parapijos kapinėse; jų pavyzdžiu pasekẻ Baisogalos bei Kupiškio šauliai, ten sutvarkę karių kapus $[101,4]$.

(23) Iki 1939 m. šauliai karių kapus tvarkè savo iniciatyva, 1939 m. rugsèjo 15 d. LŠS vadas išleido įsakymą, kuriame nurodè tvarkyti Lietuvos kariuomenès karių kapus ten, kur nebuvo reguliariosios kariuomenès dalinių, per šventes organizuoti jų pagerbimą [75].

(24) Karyje rašyta, kad buvo 500 vokiečių karių kapinių, bet 1936 m. jų buvo likę apie 200, nes vèlesniais metais juos tvarkant vokiečių, o kai kada ir rusų karių kapai buvo perkelti ị didesnes kapines [92]. 
prašydama apsaugoti Lietuvos teritorijoje buvusius Didžiojo karo vokiečių karių kapus, nepriklausomai nuo to, valstybinèje ar privačioje žemèje jie buvo [242].

Vokietijos atstovybès Kaune prašymu Lietuvos valdžia surinko duomenis apie buvusias vokiečių karių kapines ir nustatè žemès (kurioje buvo palaidojimai) priklausomybę. Tuo metu suskaičiuota 614 vietų (nors Telšių apskrities duomenys gali būti nepilni), kuriose buvo palaidoti Didžiojo karo metu žuvę kariai. Pažymėtina, kad skaičiuotos ne tik vokiečių, bet kai kur ir Rusijos karių laidojimo vietos. Nustatyti palaidotųjų skaičių iš šių sąrašų neįmanoma, nes daugelyje vietų nurodyta, kad jų skaičius nežinomas. Kapinių dydis svyravo nuo pavienio kapo iki kelių tūkstančių kapų; didžiausios jų buvo Tauragèje (apie 3 000), Panemunejje (1 622), Armoniškių k. Kauno apskr. (1 500), Šiauliuose (apie 1500 vokiečių karių kapų). Daugiausiai vietų, kur palaidoti šie kariai, būta Trakų (123), Alytaus (102) ir Kauno (76) apskrityse, bet ar ten buvo daugiausia ir palaidotųjų, dèl minèto duomenų stygiaus nustatyti neįmanoma. Mažiausiai kapinių buvo Utenos (1), Mažeikių (2) ir Kretingos (3) apskrityse [sąrašus žr. byloje 256].

1928 m. Rusijos episkopalinio sinodo Vyriausiasis ịgaliotinis karo nuostoliams ir karžygių kapams užsienyje kreipėsi ị Lietuvos Vidaus reikalų ministeriją prašydamas pateikti duomenis apie Rusijos kariuomenės karius, karo belaisvius ir civilius, žuvusius Didžiojo karo metu ir palaidotus Lietuvos teritorijoje [209]. Apskričių surinktais duomenimis, buvo 649 kapinès, kuriose buvo palaidota 37120 asmenų (nežinoma, kiek iš jų buvo civiliai). Tačiau šie skaičiai apytikriai - dalis kapinių buvo bendros Rusijos ir Vokietijos karių, kai kuriose kapinèse palaidotųjų skaičius nebuvo žinomas [215].

1929 m. Lietuvos Vidaus reikalų ministerijos duomenimis, Lietuvos teritorijoje buvo 465 vietos, skirtos ne kapinėms, kuriose buvo palaidota 23020 Didžiojo karo Vokietijos kariuomenès aukų. Kapai daugiausia buvo privačiose valdose ir juos tvarkè Vokietija [189]. Tarpukario Lietuvoje, be Klaipėdos ir Vilnius kraštų, po Didžiojo karo buvo per 500 vokiečiu karių kapinių; Vokietijos valdžios nurodymu jas tvarkant dalis vokiečių, o kai kada ir rusų karių buvo perlaidoti ị didesnes kapines, kurių 1936 m. buvo apie 200. Remiantis surinkta statistika, Lietuvoje buvo palaidota apie 35000 Didžiojo karo karių, iš jų - 23000 Vokietijos ir 12000 Rusijos kariuomenių karių. Daryta prielaida, kad su Klaipėdos ir Vilniaus kraštais palaidotų Didžiojo karo karių Lietuvoje buvo apie 50 tūkst., o gal ir daugiau. Pabrěžta, kad abiejose kariuomenėse tarnavo bei žuvo ir lietuvių tautybès kariai. Daug Prūsijos lietuvių žuvo per Kauno tvirtovės šturmą, rašyta, kad Lietuvoje galèjo būti palaidota „keliolika šimtų lietuvininkų“ [92]. Vèlesniais metais 35 tūkst. Didžiojo karo karių, palaidotų Lietuvos Respublikos teritorijoje, skaičius jau buvo laikomas oficialus [100,606].

Galimos dvi tokio ženklaus Vokietijos ir Rusijos žuvusių karių skaičiaus skirtumo versijos: Vokietijos kariuomenė 1915 m. Lietuvoje vykdè puolamuosius veiksmus, todèl hipotetiškai galejo patirti daugiau nuostolių nei besiginančios Rusijos pajègos; tačiau labiau tikètina, kad besitraukdama Rusijos kariuomenè neturèjo galimybès deramai palaidoti, suskaičiuoti ir pažymėti savo aukų, o puolančios Vokietijos pajegos užimdavo buvusių mūšių teritorijas, todèl galèjo su joms būdingu preciziškumu laidoti savo karius ir deramai paženklinti jų kapavietes.

Kapai nebuvo naikinami, tačiau susitarimas tarp Vokietijos ir Lietuvos dẻl Didžiojo karo Vokietijos karių kapų priežiūros Lietuvos teritorijoje nebuvo pasiektas. Tuo užsièmė Volksbund Deutsche Kriegsgräberfürsorge, taigi gražiai tvarkomi vokiečių karių kapai buvo geras visiems matomas pavyzdys Lietuvoje [62]. Atskirų vokiečių karių kapinių tvarkymu 
rūpinosi minètos organizacijos tam tikri skyriai (25): Kauno kapinėmis - Volksbund centro valdyba, Biržų - Hanoverio, Panevėžio - Esseno skyrius ir t. t. [101, 3]. Spaudoje rašyta, kad Vokietija net užsienyje palaidotų savo karių nepamiršta, prižiūri jų kapus, o Lietuvoje net savame krašte palaidotų karių kapai yra apleisti [267], ir siūlyta sekti vokiečių pavyzdžiu tvarkant karių kapus [59; 252; 254] (26). Kai 1927 m. vokiečių organizacijos ėmèsi perlaidoti ir tvarkyti savo karių kapus, Rusija nerodė jokio susidomèjimo karių kapais [35]. Lietuvoje su tam tikra nuostaba konstatuota, kad „vokiečiai neapleidžia ir savo priešų kapinių“ [226].

Karių kapų tvarkymas Latvijoje, ypač Brolių kapai Rygoje, buvo kitas pavyzdys, leidęs konstatuoti, jog kaimyninėse šalyse žuvę kariai buvo gerbiami, o jų kapai prižiūrimi ir puoselejjami [14;15;121;165] (27). „Reikia tik stebètis, kaip latviai gerbia savo žuvusius ir atsidejję su meile laidoja savo karžygius gražioje vietoje“, - rašyta to meto spaudoje [227]. 1925 m. Latvijos pavyzdžiu siūlyta steigti Lietuvoje draugiją, kuri rūpintųsi karių kapų priežiūra, šiam tikslui rinktų lèšas [45].

Ne visi karių kapai buvo prižiūrimi, nors ir atkreiptas ị tai demesys. 1926 m. Karyje nuogąstauta, kad šalia Alytaus-Jiezno kelio buvusių pasaulinio karo karių kapų niekas neprisimena. Buvo siūloma tų kapų priežiūrą pavesti Lietuvos kariuomenès Alytaus igulos kariams (28). Kaišiadorių parapijos kapinès taip pat buvo apleistos. 1933-1934 m. šauliai sutvarkè ten palaidotų nepriklausomybès kovų karių kapus, tačiau spaudoje greta pagyrimo teigta, jog būtina sutvarkyti ir 5 kapus šalia palaidotų kazokų (,jų kapai visai virtę dirvonu ir niekieno neprižiūrimi: gyvuliai ganosi, visų mindžiojami“), kuriuos Didžiojo karo metu sušaudè vokiečiai [138; 139].

1925 m. dienraštyje Rytas, aptariant Lietuvoje kilusį susirūpinimą dèl karių kapų tvarkymo, buvo skelbiama, kad „mūsų [Lietuvos - V. J.] jaunimas pradeda daugely vietų rūpintis sutvarkyti ir palaikyti visų žuvusiųjų Lietuvoje per Didijji karą rusų ir vokiečių armijų kareivių kapus, kurių tarpe yra ne maža ir mūsiškių. Ir tai būtinas ir garbingas darbas“ [58]. Tačiau ryškesnị pokytị galima pastebèti XX a. 4-ojo dešimtmečio pradžioje. 1930 m. Liudvinavo šaulių būrys pradejjo tvarkyti ir puošti ten palaidotų Didžiojo karo karių kapus [231; 240]. 1930 m. gegužès 11 d. Kẻdainių šaulių būrio susirinkime šaulys Zvicevičius pateikè pasiūlymą „sutvarkyti žuvusiųjų Didžiojo karo metu karių kapus Kèdainių miesto kapuose“ ir jam buvo pritarta [205]. $1931 \mathrm{~m}$. šauliai perlaidojo pakelèje užkasto Rusijos kariuomenès kario palaikus į Stelmužès dvaro vokiečių karių kapines, kad jų nemindžiotų galvijai [206]. XX a. 4-ojo dešimtmečio pirmoje pusèje Lietuvoje

(25) Daugelyje vietų stovejjo monumentalūs paminklai, dalis jų kartu su karių kapinėmis sovietmečiu buvo sunaikinti [159, 99, 112, 123, 130, 131, 167, 177, 197].

(26) Atkreipiant demesị ị apleistus Lietuvos karių kapus Kauno kapinèse, rašyta: „Kaip nuraminsi karžygio močiutę, susigraudinusią dèl savo sūnaus kapo, apleisto usnimis ir suardyto, kada čia pat greta, per dešimtị žingsnių ji mato kitą kapinių dalį akmeniniais kryžiais, gražiais takeliais, gèlèmis, medeliais išpuoštą? (vok. karių kapai)“ [265].

(27) Teigta, kad „mes ne tik turime su latviais panašias valstybes, ne tik mūsų tautos giminingos, bet turime daug kovos laimejjimų ir pralaimejjimų panašumo, turėjome vienus ir tuos pačius priešus ir t. t. Bet ne vienodai įvertiname žuvusių dèl tèvynès aukas - vieni daugiau, antri mažiau arba ir visai neicvertiname" [7].

(28) „Niekas neatmena šių vyrų, žuvusių pasauliniame kare. Kapinès, kur palaidoti ir mūsų broliai [,] giminès greta su rusų nemažu skaičiumi [,] matyt, senai žmonių nebeatmenami [,] maži suklypę kryželiai, nublukę parašai. Vienas gražus akmeninis paminklas galètų stovèti per ilgas metų eiles ir puošti kapines. Reikia tiktai žmonių noro“ [143]. 
buvo prižiūrimi Vokietijos ir Lietuvos kariuomenių karių kapai, tačiau apleisti Rusijos kariuomenès karių kapai, nors tradiciškai pabrěžta, kad „nereikia pamiršti, kad tarpe tų nežinomų rusų karių galèjo būti ir mūsų tautiečių - lietuvių“, nes Didžiojo karo pradžioje Lietuvoje buvo ịvykdyta plataus masto mobilizacija ị Rusijos kariuomenę [95]. 1933 m. Trimite ị klausimą, „Ar yra reikalas šauliams taisyti žuvusių didžiajame kare rusų karių kapus?“, buvo pateiktas vienareikšmiškas atsakymas - „Kieno kapai bebūtų: ar rusų, ar kitų ar šiaip apleisti senkapiai, reikètų, vietos gyventojams padedant, sutvarkyti, bent aptverti, kad gyvuliai nemindžiotų“, nes „kapų tvarkymas - paprotys palaikytinas ir skleistinas“, kadangi „gražiai sutvarkytos, gèlių ir medžių prisodintos kapinès, tiesūs ir gražūs smèliu barstyti takeliai kiekvienam praeiviui rodys mūsų kultūringumo žymę" [172] (29). 1933 m. balandžio 2 d. susirinkime Višakio Rūdos šaulių būrys nutarè papuošti Didžiojo karo karių kapus [71]. 1934 m. Alytaus šauliai viešai pasižadèjo pavasarị sutvarkyti būrio ribose buvusị apleistą Didžiojo karo kario kapą [204]. 1934 m. Trimite buvo išspausdinta nuotrauka su užrašu: „Veiverių šaulès ir šauliai kasmet tvarko ir puošia nepriklausomybès ir didžiojo karo dalyvių - karių kapus" [160]. 1934 m. skelbta, kad Rūdos būrio šauliai jau anksčiau sutvarkẻ Rūdos miško pakraštyje buvusias apleistas Didžiojo karo karių kapines, kuriose buvo palaidoti 135 Vokietijos ir Rusijos kariuomenių kariai. Kapines šauliai tvarkydavo kiekvieną pavasarị [253]. 1935 m. Verstaminų apylinkėse buvusias apleistas Didžiojo karo karių kapines sutvarkè vietos šauliai. Gausiai dalyvaujant vietos visuomenei buvo pastatytas ir pašventintas kryžius [89]. 1936 m. spaudoje džiaugtasi, kad Maironiuose (kaimas netoli Kelmès) Didžiojo karo karių kapus tvarko vietos gyventojai, „gražu, kad mokame gerbti, nors ir svetimus žuvusius karius" [28]. 1936 m. Nepriklausomybės kovų karių kapų tvarkymo komisija, atsižvelgdama ị tai, kad šalyje buvo daug apleistų Didžiojo karo karių kapų, kreipèsi ị valsčius, kad būtų paskirti sklypai ir juose įrengti brolių kapai „rusų bei vokiečių“ kariams [214]. 1937 m. Kačerginès miške Zapyškio šauliai sutvarkė apleistus Didžiojo karo karių kapus - „naujai sukasė kapus, iškirto brūzgus ir pastatė naują kryžių su atitinkamu užrašu“ [12; 72]. Ši šaulių veikla užfiksuota - 1937 m. Trimite buvo išspausdinta nuotrauka su užrašu: „Zapyškio būrio šauliai tvarko Did. karo žuvusių karių kapus“ [161]. 1937 m. gegužès $1 \mathrm{~d}$. Padovinyse (Marijampolès apskr.) šaulių būrys organizavo medelių sodinimo talką, kurios metu buvo apsodinti šaulių paminklas, mokyklos teritorija, vieškeliai ir Didžiojo karo karių kapai, iš viso pasodinta 400 medelių [70]. 1940 m. pavasarị Griškabūdyje moterų šaulių iniciatyva buvo "gražiai sutvarkyti Didžiajame kare žuvusių karių kapai“ [232]. XX a. 4-ajame dešimtmetyje reikšta pagarba ir Didžiojo karo metu žuvusiems Vokietijos kariams, palaidotiems Lietuvoje, nes „pats kario vardas jau yra vertas pagarbos“ (30). Tiesa, gana dažnai iš žinučių spaudoje neįmanoma nustatyti, kokius (Lietuvos nepriklausomybès kovų ar Didžiojo karo) karių kapus tvarkė šauliai, nes tik konstatuota - „šauliai sutvarkẻ karių kapus“, be konkretaus įvardijimo. Tačiau net ir esama empirinė medžiaga atskleidžia, kad šauliai ir visuomenè tvarkẻ bent dalị Didžiojo karo karių kapų, dažniausia Rusijos kariuomenès, nes Vokietijos buvo tvarkomi vokiškų organizacijų.

(29) Teigta, kad tvarkant Didžiojo karo Rusijos kariuomenès karių kapus „būtų atlikta žmoniškumo (pareiga, būtų atliktas darbas, kuris pakeltų mus mūsų ir svetimų akyse" [95, 212].

(30) „Privažiuojame Jèzną. Čia pakelèje pamatom vokiečių karių kapus. Iššokę iš mašinos, subejgame pasižiūrèti mūro sienoje iškaltų pavardžių. Rimtis ir susikaupimas dvelktelèja visų širdyse, nes čia ilsisi kariai, kovoję ir kritę kovos lauke dẻl savo siekiamų tikslų. Nors jie nèra mūsų tėvynès kariai, dargi jie net buvę mūsų krašto okupantai, tačiau vis tiek pats kario vardas jau yra vertas pagarbos. Kario vardas yra ir mūsų laisvès simbolis" [136]. 


\section{IŠVADOS}

Literatūra karo tema tarpukario Lietuvoje, viena vertus, buvo analizės objektas, kita vertus, ir tam tikra leidybos sritis - versti užsienio autorių darbai bei publikuoti vietinių rašytojų kūriniai. Didysis karas buvo ryškus kartos ịvykis, pakeitęs žmonių gyvenimą ir požiūrị i karą, atvèręs naujus karo literatūros horizontus. Dẻl visuotinès karo tarnybos daugybė jaunų gabių žmonių kelerius metus praleido fronte, o vèliau, remdamiesi šia patirtimi arba net savais dienoraščiais, parašè literatūros klasika tapusius veikalus. Lietuvoje pirmiausia imtasi vertimų, lūžio tašku galime laikyti romano Vakaru fronte nieko naujo leidybą, po kurio sekè ir lietuvių autorių darbai. Taigi XX a. 4-asis dešimtmetis buvo literatūros Didžiojo karo tema tam tikro proveržio Lietuvoje metas. Žinoma, lietuvių autoriai neprilygo tokiems autoriams kaip A. G. H. Barbusse’as, E. Jüngeris, E. M. Remarque’as, R. Dorgelès, J. Hašekas ir kt. bei jų kūrybai, gal tik išskyrus palankiai ivvertintą A. Uspenskio knygą, kuri taip pat buvo paremta autoriaus, kaip kario, asmenine patirtimi. Didysis karas tapo grožinès literatūros tarpukario Lietuvoje siužetų pagrindu, o komercinè leidyba byloja buvusị skaitytojų susidomejjimą tokia kūryba.

Galima išskirti kelis svarbesnius Didžiojo karo epizodus tarpukario Lietuvoje - pirmiausia tai jo pradžia ir priežastys bei Vokietijos okupacija, taip pat lietuvių karinę patirtị atskleidę karo veiksmai - 1914 m. Rytų Prūsijoje, 1915 m. Augustavo kautynès ir Kauno tvirtovès žlugimas. Tai lèmé geografiniai ir tautiniai motyvai - karo veiksmai vyko „lietuviškose žemèse“ ir gausiai dalyvaujant (kovojant) lietuviams. Karas vertintas prieštaringai - viena vertus, buvo daug aukų ir milžiniškų materialių nuostolių, dèl jo pašlijo moralè, pakito iki tol ịprasta gyvensena ir pasaulèžiūra. Kita vertus, karas „pabudino“ lietuvių tautą ir sudarė sąlygas atsikurti Lietuvos valstybei, o tai be užuolankų įvardyta tikru stebuklu, kuris be Didžiojo karo (kartu ir trijų Europos imperijų žlugimo) laikytas neįmanomu. Taigi Didžiojo karo aukos tapo aukomis ant Lietuvos „laisvės aukuro“, o šị teiginị stiprino ir tai, kad daug lietuvių karių dalyvavo Didžiajame kare, tarnaudami ịvairių šalių (pirmiausia Rusijos, Vokietijos ir JAV) kariuomenèse - dalis jų žuvo ịvairiuose frontuose.

Tarpukariu Lietuvoje viešajame diskurse nuolat iškildavo Didžiojo karo leitmotyvas, paliečiama ịvairi su šio karo ritualiniu atminimu susijusi praktika. Didžiojo karo sukakčių minėjimai turejjo aiškų politinị atspalvị ir kito priklausomai nuo Lietuvos užsienio politikos aktualijų. Išskirtini du epizodai - XX a. 3-iojo dešimtmečio pabaigoje pagerèję santykiai su Vokietija ir orientacija ị Prancūziją 4-ojo dešimtmečio antroje pusejje. Pastarasis epizodas, daug ryškesnis ir ilgesnis, buvo susijęs su Vokietijos kelta karine grèsme Lietuvai dèl Klaipėdos krašto, taip pat siekiu užkardyti (apriboti) vokiškos kultūros įtaką Lietuvoje. Todèl bandymo kultūriškai suartèti su Prancūzija kontekste iškilo ir Didžiojo karo suderinto abipusio atminimo svarba, pabrèžiant, kad lietuviai petys petin kovojo su prancūzais $1914-1918$ m. ir net 1812 metais. Šia veikla užsièmé Lietuvių-prancūzų draugija, kurioje aktyviai dalyvavo ịtakingi to meto Lietuvos asmenys. Taigi lietuvius ir prancūzus, o kartu Lietuvą ir Prancūziją, turejjo suartinti bendros kovos patirtis ir bendro priešo (Vokietijos) grèsmè. Galima rasti užuominų ir apie tai, kad lietuviai gynė Prancūziją (1914 m. kovojo Rytų Prūsijoje, o vèliau JAV kariuomenès sudètyje Vakarų fronte). Atsižvelgiant ị suaktyvejjusią Lietuvių-prancūzų draugijos veiklą rengiant Didžiojo karo minejjimus ir 1937 m. pradètą Didžiojo karo lietuvių karių (tarnavusių Antantès šalies - Rusijos imperijos - kariuomenejje) Pirmūnų sąjungos aktyvią veiklą siekiant pastatyti paminklą visiems Didžiajame kare žuvusiems lietuviams, galima daryti prielaidą, kad jei ne prasidèjęs Antrasis pasaulinis karas, su Pirmuoju karu susijusio 
turinio cirkuliacija Lietuvoje tikriausiai būtų buvusi dar intensyvesnè ir pereitų iš diskurso ị ritualų lygmenị.

Didžiojo karo karių kapų Lietuvoje tvarkymo ir priežiūros klausimas turẻjo aiškų nacionalini požymį. Vokietijos karių kapus nuo pat 1919 m. tvarkè Volksbund, tad lietuviškoje spaudoje buvo nuolat akcentuojamas šis pavyzdys, kaip ir kaimyninės Latvijos, kurioje Didžiojo karo karių kapų tvarkymas prasidejo dar šio karo metu. Lietuvos visuomenès ir institucijų santykis tarpukariu ị karių kapus išskirtinas ị du periodus - iki 1927 m. ir po jų. Pirmuoju karių kapų priežiūros praktika reta: netgi nepriklausomybès kovų karių kapai tuo metu buvo apleisti ir primiršti, o Didžiojo karo karių kapai kartais tapdavo nepagarbaus elgesio objektais (nors Vokietijos kariuomenès karių, o kai kada ir Rusijos kariuomenès karių kapus tvarkè Volksbund). Nuo 1927 m., pasiremiant vokiečių ir latvių pavyzdžiais, sistemingai pradèta tvarkyti nepriklausomybės kovų karių kapus, pamažu atkreiptas dèmesys ir ị Didžiojo karo karių kapų tvarkymą. Konkretūs darbai fiksuojami XX a. 4-ajame dešimtmetyje. Karių kapų priežiūra buvo pabrèžiama pagarba žuvusiems kariams, nepriklausomai nuo jų kilmès, ir laikyta tautos kultūros lygio indikatoriumi. Apsisprendžiant tvarkyti karių kapus, buvo svarbu ir tai, kad dalis Didžiojo karo metu žuvusių ir Lietuvos teritorijoje palaidotų karių (tarnavusių tiek Rusijos, tiek Vokietijos kariuomenèse) buvo lietuvių kilmės asmenys, nors toji kilmė dažnai subjektyviai nustatoma remiantis tik epitafijose užfiksuotais asmenvardžiais.

Gauta 20161205

Priimta 20170110

\section{Šaltiniai ir literatura}

[1] 1914 - VIII. 1 - 1939. Karys, 1939, rugpjūčio 3, Nr. 31 (1051), p. 911.

[2] $1937 \mathrm{~m}$. liepos 8 d. Lietuvių-prancūzų draugijos pranešimas „Alliance francaise“ kongresui Paryžiuje. $L C V A$, f. 945 , ap. 1, b. 30, 1. 8.

[3] 1939 m. turinio rodyklè. Trimitas, 1939, gruodžio 22, Nr. 51-52 (992-993), p. 1265-1270.

[4] 20 metų. Lietuvos žinios, 1934, rugpjūčio 1, Nr. 173 (4559), p. 1.

[5] A. J. Latvijos nepriklausomybès ir kariuomenès šventès proga. Kardas, 1935, lapkričio 15, Nr. 22 (227), p. 489-491.

[6] A. Kas turètų rūpintis karių kapais. Karys, 1925, liepos 29 - rugpjūčio 6, Nr. 31 (323), p. 241.

[7] A. Latvių karių kapai. Karys, 1924, rugpjūčio 21-27, Nr. 34 (274), p. 281-282.

[8] AMBRAZEVIČIUS, J. Karys ir karas literatūroje. Židinys, 1935, lapkritis, t. XXII, Nr. 11 (131), p. 377-385.

[9] ANTALGIŠKIS. Kvieskime užjūrio brolius. Trimitas, 1929, balandžio 18, Nr. 16, p. 257.

[10] Apdovanojimai prancūzų ordinais. Lietuvos aidas, 1938, gruodžio 3, Nr. 549 (4358), p. 3.

[11] Apleisti karių kapai. Karys, 1925, rugsėjo 10-16, Nr. 37 (329), p. 294.

[12] ASTRAUSKAS, J. Sutvarkè karių kapus. Karys, 1937, spalio 14, Nr. 42 (969), p. 1204.

[13] Atsiliepimai apie plk. A. Uspenskio knygą „Didžiajame Kare“. LCVA, f. 384, ap. 5, b. 32, 1. $126-127$.

[14] B. P. Kaip tvarkomi latvių karių kapai. Kardas, 1927, birželio 10, Nr. 16 (76), p. 231.

[15] B. P. Karių kapų draugijos darbai 1925 m. Kardas, 1926, birželio 10, Nr. 16 (40), p. 258.

[16] BAISIOGALIETIS-ŠAULYS. Kodèl Baisiogaloje pastatytas paminklas. Trimitas, 1928, spalio 25, Nr. 43 (412), p. 1393.

[17] BARBUSSE, Henri. Mirtis dumble. Iš karo romano „Ugnis“. Kultūra, 1934, Nr. 6-7 (128-129), p. 363-371. 
[18] BARBUSSE, Henri. Ugnyje [pasaulinio karo vaizdai]. Brooklyn: Amerikos lietuvių darbininkų literatūros draugija, 1928. $431 \mathrm{p}$.

[19] BARBUSSE, Henri. Ugnis (skyriaus dienoraštis). Vilnius: Valstybinè grožinès literatūros leidykla, 1954. $417 \mathrm{p}$.

[20] BARDAUSKAS, J. Pasaulinio gaisro kilmè. Kultūra, 1934, Nr. 6-7, p. 323-340.

[21] BARTNINKAITÉ-RŪTELIONIENĖ, Petronèlè. Klaikuma: iš Didžiojo karo laikų ir tremtiniu gyvenimo. T. I. Romanas. Kaunas: Aitra, 1930. 329 p.

[22] BARTUŠKA, Vincas. Kelioné Lietuvon. Didžiosios Karès Metu 1916 m. Boston: Darbininkas, 1916. $85 \mathrm{p}$.

[23] BARTUŠKA, Vincas. Lietuvos nepriklausomybès kryžiaus keliais. Kritiškas 1914-1919 metu ivykiu ir asmenybiu įvertinimas. Klaipeda: akcine Ryto b-vès sp., 1937. 391 p.

[24] BIČIŪNAS, [Vytautas Pranas]. Mirusieji ir gyvieji. Trimitas, 1933, lapkričio 2, Nr. 44, p. 862.

[25] BIČIŪNAS, [Vytautas Pranas]. Pavasario balsų dainius. Trimitas, 1934, birželio 28, Nr. 26, p. 513 .

[26] [BINKIS, Kazys] A. A. Uspenskij NA VOINE. Literatūros naujienos, 1934, rugsëjo 15, Nr. 10, p. 5.

[27] BYTAUTAS, Adomas. Senos pilies paslaptis. Kaunas: Šviesa, 1937. 144 p.

[28] B-NAS, J. Gražiai sutvarkè karių kapus. Karys, 1936, balandžio 2, Nr. 14 (889), p. 343.

[29] BOLECKIS, [Kostas]. Kauno tvirtovès gynimas. Mūsu žinynas, 1923, t. V, Nr. 14, p. 250-267.

[30] BRAZIULIS, A. Dim. pulk. Aleksandras Uspenskis. Didžiajame kare. Trimitas, 1936, vasario 20, Nr. 8 (793), p. 192.

[31] BRČ. I. 20 ir 15. Lietuvos karo invalidas, 1938, Nr. 1, p. 14-19.

[32] BR-LAS. Karių kapai. Karys, 1922, birželio 17, Nr. 24 (160), p. 181-182.

[33] BROLIŲ TOMDYKŲ. [BURČIKAS, Adolfas]. Augustavo mišku prakeikimas. Kaunas: [s. n.], $1934.96 \mathrm{p}$.

[34] B-S, V. F. G. Lebos, Nekaltujų kraujas. Trimitas, 1935, rugpjūčio 29, Nr. 35 (768), p. 620.

[35] BŪDIŠKIS, Vl. Gerbkime karių kapus. Karys, 1927, gruodžio 7-13, Nr. 49 (445), p. 454.

[36] BUKAITĖ, Vilma. Lietuvos Respublikos politiniai ir diplomatiniai santykiai su Prancūzija 1919-1940 m. [daktaro disertacija]. Vilnius: Vilniaus universitetas, 2013. 333 p.

[37] BŪTĖNAS, Julius. Didžiojo karo literatūra. Kultūra, 1930, Nr. 8, p. 406-412.

[38] BŪTĖNAS, Julius. Didžiojo karo literatūra. Kultūra, 1930, Nr. 9, p. 476-480.

[39] BŪTĖNAS, Julius. Karo literatūros tendencijos. Kultūra, 1934, Nr. 6-7 (128-129), p. 341-344.

[40] BŪTĖNAS, Julius. Lietuvių teatras Vilniuje vokiečių okupacijos metu. Trimitas, 1934, lapkričio 8, Nr. 45, p. 874-875.

[41] Chadži-Muratai Mugujevas. Ir Rytų Fronte Nieko Naujo (Bagdado vartai). Romanas. Trimitas, 1931, liepos 16, Nr. 29, p. 579.

[42] CONDENHOVE-KALERGI, Richard Nikolaus. Dvidešimties metų karas. Didžiojo karo pradžios 20-ties metų sukaktuvių proga. Lietuvos aidas, 1934, liepos 30, Nr. 171 (2138), p. 2.

[43] CONDENHOVE-KALERGI, Richard Nikolaus. Dvidešimties metų karas. Rytas, 1934, rugpjūčio 2, Nr. 174 (3026), p. 4.

[44] CVEIGAS, [Arnold]. Vokiečių okupacija Lietuvoje (Iš knygos: „Ginčas dẻl seržanto Grišos“). Vertè K. Binkis. Trimitas, 1929, birželio 6, Nr. 23, p. 373-375.

[45] D. Dèl karių kapų tvarkymo, lešųu ir dèl draugijos. Karys, 1925, liepos 9-15, Nr. 28 (320), p. 217.

[46] DARMANTAS, V. Šaulių Sajunga 1933 metais. Trimitas, 1934, vasario 15, Nr. 7, p. 125-131.

[47] Didžiais žygiais ir didžiais darbais tauta rašo sau istoriją. Valstybès Prezidento Antano Smetonos kalba, pasakyta lietuvių karių Rusijoje sąūiž̌io 20 metų sukakčiai paminèti (rugsejo $8 \mathrm{~d}$. 
Karo muziejus). Lietuvos karo invalidas, 1937, Nr. 1, p. 25.

[48] Didžiojo karo laiku lietuviu dainos. Surinko Jonas Norkus. Kaunas: Vairo b-vè, 1927. 239 p.

[49] Didžiojo karo paliaubų minèjimas. Trimitas, 1934, lapkričio 15, Nr. 46, p. 888.

[50] Didžiojo karo rezultatai. Kultūra, 1935, Nr. 11, 681-684.

[51] Didžiosios paliaubos. Lietuvos aidas, 1928, lapkričio 10, Nr. 231 (445), p. 2.

[52] DILYS, A. Rūpinkimès karių kapais! Karys, 1924, birželio 5-11, Nr. 23 (263), p. 189-190.

[53] DORGELÈS, Roland. Mediniai kryžiai: did. karo romanas. Kaunas: Sakalo b-vé, 1931. 216 p.

[54] Dubysa - karo tvirtove. Karys, 1937, liepos 8, Nr. 28 (955), p. 764.

[55] EIS. Roland Dorgelèi. Mediniai Kryžiai. Did. karo romanas. Trimitas, 1931, liepos 16, Nr. 29, p. 579 .

[56] ENDZIULAITIS. Iš 3. peest. pulko gyvenimo. Kardas, 1926, gegužès 20, Nr. 14 (38), p. 222.

[57] ESČE. 10-os rusų armijos XX korpuso veiksmai Rytų Prūsuose (1915 m. vasario 9-21 d.). Mūsu žinynas, 1921, t. I, Nr. 3, p. 181-196.

[58] ET. Žuvusių karių pagerbimas. Rytas, 1925, gegužè 26, Nr. 111 (416), p. 1.

[59] FIGŪRINAS. Gerbkime žuvusių karių kapus. Karys, 1926, kovo 4-10, Nr. 10 (354), p. 91.

[60] GIEDA. Aurelijus. Istoriografija ir visuomene: istorija, istoriko profesijos ir istorinès kultūros aspektai Lietuvoje 1904-1940 m. [daktaro disertacija]. Vilnius: Vilniaus universitetas, 2013. 482 p. [61] GIMŽAUSKAS, Edmundas. Vokietijos Pirmojo pasaulinio karo tikslai Rytuose: istorijos ir istoriografijos vingiai. Lietuvos istorijos metraštis 2014 metai, 2015, t. II, p. 125-153.

[62] GIRININKIENE, Vida. Jie nenorèjo mirti. Lietuvos žinios, 2014, spalio 31, p. 18-19.

[63] GRAUROGKAS, [Antanas]. Šauliškumas ir gyvenimo raida. Trimitas, 1934, gegužès 3, Nr. 18, p. 350-351.

[64] GRAŽEVIČIUS, A. Kas karus kelia? Pavasaris, 1934, rugpjūčio 1, Nr. 14, p. 386-388.

[65] GRIFFANTE, A. Gemeinschaft und Mythos. Zwei litauische Narrative über den Ersten Weltkrieg (1914/15). Nordost-Archiv, Der Große Krieg beginnt: Sommer und Herbst 1914. 24. Jahrgang 2015. 2016, S. 97-113.

[66] GRINIUS, [Kazys]. Dvidešimtąją Didžiojo karo pradžios sukaktị minint. Mūsų žinynas, 1934, t. XXVII, Nr. 113, p. 112.

[67] HAŠEK, Jaroslav. Šaunusis kareivis Šveikas. Kaunas: Spaudos fondas, 1932. 178 p.

[68] HAŠEK, Jaroslav. Šaunusis kareivis Šveikas: Šveikas ruošiasi kariauti. Kaunas: Naujasis Žodis, 1932. $177 \mathrm{p}$.

[69] Istorinès dienos prieš 20 metų. Lietuvos aidas, 1938, lapkričio 11, Nr. 511 (4320), p. 6.

[70] Iš šaulių gyvenimo. Padovinys. Trimitas, 1937, gegužès 13, Nr. 19 (856), p. 452.

[71] Iš šaulių gyvenimo. Višakio Rūda. Trimitas, 1933, balandžio 27, Nr. 17, p. 336.

[72] Iš šaulių gyvenimo. Zapyškis. Trimitas, 1937, rugsèjo 11, Nr. 36 (873), p. 859.

[73] IVINSKIS, Zenonas. Didžiosios Europos valstybès 1898-1914 m. ir D. karo priežastys. Židinys, 1934, liepa, t. XX, Nr. 7, p. 3-13.

[74] I visuomenę. Karys, 1922, liepos 21, Nr. 29 (165), p. 348-349.

[75] Isakymas Šaulių sąungai, Nr. 37, 1939 m. rugsèjo 15 d. Trimitas, 1939, rugsèjo 21, Nr. 38 (979), p. 912.

[76] İvairenybès. Amerikos teismų sprendimai. Trimitas, 1924, lapkričio 6, Nr. 212, p. 28.

[77] İvairenybès. Sąžinès fondas. Trimitas, 1924, rugsèjo 25, Nr. 206, p. 30.

[78] J. B. Kultūriniai kariuomenès laimèjimai. Karys, 1939, rugsèjo 7, Nr. 36 (1056), p. 1058-1059.

[79] J. Karių kapai Vilniuje. Karys, 1940, birželio 6, Nr. 23 (1103), p. 619.

[80] J. Užsienio svečiai Lietuvoje. Kardas, 1928, gegužès 30, Nr. 15 (111), p. 216-217.

[81] JAKŠTAS, [Petras]. Karių kapai. Lietuvos karo invalidas, 1930, Nr. 1, p. 27. 
[82] JAKŠTAS, [Petras]. Karių kapų tvarkymas 1930 m. Kario Nr. 10 priedas: Mūsų karių kapai, 1931, p. 1-8.

[83] JAKŠTAS, [Petras]. Karių kapų tvarkymas 1935 m. Karys, 1936, vasario 16, Nr. 7 (882), p. $158-160$.

[84] Jaroslav Hašek. Šaunusis kareivis Šveikas. Karys, 1932, spalio 20, Nr. 43 (699), p. 860.

[85] JOKUBAUSKAS, Vytautas. „Mažuju kariuomeniu“ galia ir paramilitarizmas. Tarpukario Lietuvos atvejis. Klaipèda: Klaipèdos universiteto leidykla, 2014. 588 p.

[86] JONAITIS, F. Jurgis. Keturi angelai: pasakojimas iš Didžiojo karo meto. Kaunas: [s. n.], 1927. $71 \mathrm{p}$.

[87] JONAITIS, F. Jurgis. Mano Patyrimai Didžiojoj Karēj 1918 ir 1919 metais. Boston: Lietuvių prekybos bendrove, $1920.64 \mathrm{p}$.

[88] JÜNGER, Ernst. Plieno audrose. Vilnius: Kitos knygos, 2016. 284 p.

[89] JUODIS. Sutvarkè karių kapus. Karys, 1935, gruodžio 12, Nr. 50 (873), p. 1250.

[90] JUODLIS. Neužmirškime Eimučio. Karys, 1923, birželio 21-27, Nr. 25 (213), p. 294-295.

[91] JURGELIONIS, [Antanas]. Sveikatos, mankštinimo ir gynimosi institucijų sąryšis. Kardas, 1925, lapkričio 1, Nr. 20, p. 1-5.

[92] JURINAS. Lietuviai kariai, žuvę Vokietijos ir Rusijos kariuomenèse. Karys, 1936, lapkričio 12, Nr. 46 (921), p. 1171.

[93] K. A. Nepamirškime žuvusių už mūsų laisvę. Lietuvis, 1925, kovo 6, Nr. 10, p. 4.

[94] K. Latvių 10 m. nepriklausomybès sukaktuves paminejjus. Trimitas, 1928, lapkričio 22, Nr. 47 (416), p. 1514.

[95] K. Š. Pamirštų kapų tvarkymo reikalu. Mūsų girios, 1934, balandis, Nr. 4 (30), p. 211-212.

[96] Kaip Kaune buvo tvarkomi karių kapai. Karys, 1927, gruodžio 20-31, Nr. 51-52 (447-448), p. 487-488.

[97] Kaip pasibaigè Didysis karas. Trimitas, 1932, liepos 7, Nr. 28, p. 561-562.

[98] Karas ir revoliucija. Trimitas, 1924, balandžio 17, Nr. 184, p. 13-14.

[99] Karas ir taika. Tautos mokykla, 1934, rugpjūčio 15, Nr. 15-16, p. 277-279.

[100] Kariuomenè yra neatskiriama tautos dalis. Kariuomenès vado gen. št. plk. St. Raštikio kalba, pasakyta Valstybès Radiofone š. m. lapkričio 23 dieną. Kardas, 1936, gruodžio 1, Nr. 23 (252), p. 606-608.

[101] Karių kapų tvarkymas kitur ir pas mus. Kario Nr. 15 priedas: Mūsų karių kapai, 1930, balandžio 10 , p. 3-6.

[102] Karo istorijos medžiaga. Lietuva, 1921, lapkričio 20, Nr. 262 (790), p. 3.

[103] Karo istorijos reikalu. Kardas, 1936, balandžio 15, Nr. 8 (237), p. 226.

[104] Karo istorijos reikalu. Karys, 1936, gegužè, Nr. 15-16 (890-891), p. 388.

[105] Karo mokslo valdybos $1927 \mathrm{~m}$. kovo 28 d. raportas Vyriausiojo štabo viršininkui. LCVA, f. 929 , ap. 6, b. $93,1.289$.

[106] Karo sukaktuvès. Kultūra, 1934, Nr. 6-7, p. 323.

[107] KARVELIS, P. Pirmajij nepriklausomos Lietuvos ūkio dešimtmetị minint. Židinys, 1928, t. 7, Nr. 5-6, p. 398-404.

[108] Kas buvo gen. Litzmanas. Karys, 1936, liepos 2, Nr. 27 (902), p. 673.

[109] KASPARAVIČIUS, Algimantas. Didysis karas (1914-1918) ir Lietuva (nereikalingi faktai ir šešèliai istorinèje atmintyje). Santara, 2014, vasara, Nr. 105-106, p. 4-21.

[110] KASPARAVIČIUS, Algimantas. La Grande Guerre dans les mémoires historiques des Lituaniens. Matériaux pour l'histoire de notre temps, 2014, No. 1-2 (113-114), p. 58-65.

[111] Ką veikè 1928 m. karių kapams tvarkyti komisija. Karys, 1929, sausio 31, Nr. 4 (504), p. 57-58; 
Karys, 1929, vasario 5, Nr. 5 (505), p. 75-76.

[112] KEBLAS, Stasys. - M. PTOU. Pasauliniame fronte... Ekstra telegrama! [Mobilizacija 1914 metų]. T. I. Kaunas: Šviesa, 1935. 311 p.

[113] KEBLAS, Stasys. - M. PTOU. Pasaulinis karas. T. II. Ukmergè: Knyga, 1936. 208 p.

[114] KELMUTIS, A. Likviduokime neraštingumą. Trimitas, 1938, sausio 7, Nr. 1 (890), p. 10.

[115] Korespondencijos. Seredžius. Trimitas, 1925, vasario 19, Nr. 7, p. 214.

[116] Korespondencijos. Šeduva. Trimitas, 1925, kovo 5, Nr. 9, p. 283.

[117] Kovų Varpų ịsteigimo ir pašventinimo aktas. Karys, 1937, rugsejo 9-16, Nr. 37-38 (964-965), p. 1030.

[118] KRASAUSKAS, Antanas. Mirtis už fronto. Romanas. Kaunas: [s. n.], 1935. 183 p.

[119] KRAUNAITIS. Kaip prancūzai gerbia savo karžygius. Kardas, 1927, sausio 10, Nr. 1 (61), p. 14.

[120] KRIAUČIŪNIENĖ, Živilè. Lietuvos studentai Europos aukštosiose mokyklose 1919-1940 metais. Lietuvos istorijos metraštis, 1992 metai. 1994, p. 91-108.

[121] Latvių šaulių pulkų kautynių paminèjimas. Karys, 1924, sausio 17-23, Nr. 3 (243), p. 25.

[122] LEBOS, F. G. Nekaltuju kraujas. Kaunas: akc. Žaibo b-vè., 1935. 165 p.

[123] LESČIUS, Vytautas. Lietuvos kariuomené nepriklausomybès kovose 1918-1920. Vilnius: Generolo Jono Žemaičio Lietuvos karo akademija, 2004. 497 p.

[124] Lietuva Didžiajame kare. Sud. Petras Ruseckas. Vilnius: Vilniaus žodis, 1939. 336 p.

[125] Lietuviškoji dvasia atgijo Mažojoje Lietuvoje. Šaulių s-gos vado plk. Saldžiaus žodis Klaipedoje minint sausio 15 d. Trimitas, 1938, sausio 20, Nr. 3 (892), p. 49-50.

[126] Lietuvių prancūzų draugijos narių susirinkimas. Karys, 1936, birželio 10, Nr. 24 (899), p. 603.

[127] Lietuvių-Prancūzų D-jos pirmininkès Urbšienès kalba. Kardas, 1938, sausio 1, Nr. 1 (279), p. 7.

[128] Lietuvių-prancūzų draugijos 1934 m. lapkričio 2 d. prašymas. LCVA, f. 945, ap. 1, b. 27, 1. 219.

[129] Lietuvių-prancūzų draugijos $1938 \mathrm{~m}$. birželio 15 d. visuotinio susirinkimo protokolas. LCVA, f. 945 , ap. 1, b. $39,1.35$.

[130] Lietuvių-prancūzų draugijos 1939 m. gruodžio 12 d. prašymas J. E. Ponuo užsienio reikalų ministrui. LCVA, f. 945, ap. 1, b. 66, 1. 6 .

[131] Lietuvių-Prancūzų draugijos nuo 1937 m. birželio 25 d. iki 1938 m. birželio 15 d. veikimo apyskaita. LCVA, f. 945, ap. 1, b. 39, 1. 27.

[132] Lietuvių-prancūzų draugijos Valdybos metinè veikimo apyskaita nuo 1938 m. birželio 15 d. iki 1939 m. birželio 15 d. LCVA, f. 945, ap. 1, b. 39, 1. 5.

[133] Lietuvos ir Lenkijos diplomatiniai santykiai 1938-1940 metais. Sud. Algimantas Kasparavičius; Paweł Libera. Vilnius: Lietuvos istorijos instituto leidykla, 2013. 622 p.

[134] LINGEVIČIUS, Leonas. Karas 1914-1918 m. Kaunas: Šviesa, 1933. 240 p.

[135] LITZMANN, [Karl]. Kauno tvirtovès puolimas ir paemimas. Mūsų žinynas, 1930, t. XIX, Nr. 65, p. $120-142$.

[136] Lygiaisiais Lietuvos laukais. Policija, 1939, birželio 1, Nr. 11 (303), p. 218.

[137] Majorui Ramanauskui paminèti. Karys, 1923, rugsejjo 6-12, Nr. 36 (224), p. 410.

[138] MARMA, J. Pavyzdingai sutvarkè karių kapus. Karys, 1934, birželio 13, Nr. 24 (795), p. 476.

[139] MARMA, J. Šauliai sutvarkè karių kapus. Karys, 1933, lapkričio 2, Nr. 44 (761), p. 895.

[140] Matin balsas apie Lietuvą. Karys, 1936, liepos 30, Nr. 31 (906), p. 742.

[141] MB. Kaip prasidejjo pasaulinis karas. 20 m. sukaktuvių proga. Trimitas, 1934, rugpjūčio 2, Nr. 31, p. 612-615.

[142] MB. Pirmųjų karo dienų ispūdžiai. Trimitas, 1934, rugpjūčio 16, Nr. 33, p. 652-653.

[143] MEDVECKAS, A. Apleisti karių kapai. Karys, 1926, gegužès 12-18, Nr. 20 (364), p. 166.

[144] Mirè rašytoja Ona Pleirytė-Puidienè. Trimitas, 1936, sausio 30, Nr. 5, p. 99. 
[145] Mykolas Volodka. Lietuvos karo invalidas, 1938, Nr. 1, p. 70-71.

[146] MORKŪNIENĖ, Vita. Paminklas ị Tẻvynę sugrịžusiam tėvui. [žr. 201510 12]. Prieiga per internetą: $<$ http://skrastas.lt/?data=2004-12-28\&rub=1143711027\&id=1146723316 >.

[147] Motinai pagerbti diena. Trimitas, 1929, kovo 28, Nr. 13, p. 220.

[148] MUGUJEVAS, Chadži-Muratas. Ir Rytu fronte nieko naujo. (Bagdado vartai). Kaunas: Sakalas, 1931. $205 \mathrm{p}$.

[149] Mūsų ir svetimoji spauda. Kardas, 1934, rugpjūčio 15, Nr. 16 (193), p. 327.

[150] Mūsų karių kapai. Karys, 1924, gegužès 8-14, Nr. 19 (259), p. 161.

[151] Mūsų karų ir kariuomenès istorija „Karyje“ (1919-1934 metų bibliografija). Karys, 1934, Nr. 21 priedas, p. $1-16$.

[152] N. N. Karių kapai Panevežy. Kardas, 1926, birželio 10, Nr. 16 (40), p. 251-252.

[153] Napoleono žygio ir žuvusiųjų minèjimas. Kardas, 1937, lapkričio 15, Nr. 22 (276), p. 519.

[154] Napoleono žygio per Lietuvą skyrius V. D. Karo Muziejuje. Karys, 1938, sausio 1, Nr. 1, p. $15-16$.

[155] Nauji leidiniai. Karys, 1931, balandžio 9, Nr. 15 (619), p. 307.

[156] Nauji leidiniai. Karys, 1935, rugpjūčio 22, Nr. 34 (857), p. 799-800.

[157] NAUNČIKAS, [Kazys]. Mūsų karo žygiai laukia rašytojo plunksnos. Kardas, 1936, rugpjūčio 1, Nr. 15-16 (244-245), p. 425.

[158] NORKUS, J. Kaip prasidejjo didysis karas. 20 metų sukakus. Trimitas, 1934, liepos 12, Nr. 28 , p. 551-552.

[159] Nukenteję paminklai. Sud. Marija Skirmantiené, Jonas Varanauskas. Vilnius: Mokslo ir enciklopedijų leidykla, 1994. 243 p.

[160] Nuotrauka. Trimitas, 1934, gegužès 31, Nr. 22, p. 437.

[161] Nuotrauka. Trimitas, 1937, rugsèjo 23, Nr. 38 (875), p. 901.

[162] Nurodymai atsiminimus rašantiems. Kardas, 1936, liepos 15, Nr. 14 (243), p. 390.

[163] Pagerbti Didžiajame kare žuvę lietuviai ir prancūzai. Kardas, 1938, Nr. 22 (300), p. 536.

[164] PALECKIS, Justas. Didysis karas 1914-1918. Kaunas: Skaitytojas, 1939. 112 p.

[165] PALIAKAUSKAS, J. Latvijos Brolių kapai. Karys, 1935, lapkričio 7, Nr. 45 (868), p. 1072.

[166] Pamaldos karo paliaubų dienos proga. Lietuvos aidas, 1936, lapkričio 12, Nr. 521 (3137), p. 3.

[167] Pamaldos už kare žuvusius lietuvius ir prancūzus. XX amžius, 1939, lapkričio 10, Nr. 259

(1011), p. 2.

[168] Pamaldos už žuvusius 1914-1918 metų kare. Lietuvos aidas, 1939, lapkričio 10, Nr. 684 (5086), p. 8.

[169] PARLAND, Henri. Moderniškasis karo romanas. Vairas, 1930, birželis, Nr. 6, p. 261-264.

[170] Pasaulinio karo balansai. Kas apskaičiuos, kiek Lietuvai padarè didysis karas nuostolių? Lietuvos žinios, 1934, rugpjūčio 4, Nr. 176 (4562), p. 3.

[171] Pasaulio anykštènų bendrija: Stasys Keblas. [žiūrèta 201609 22]. Prieiga per internetą: $<$ http://www.anykstenai.lt/asmenys/asm.php?id=439>. [Už informaciją autorius dekkoja dr. Norbertui Černiauskui].

[172] Patarimai. Trimitas, 1933, gruodžio 7, Nr. 49, p. 981.

[173] PETRAITYTĖ, Asta. Politika per kultūrą. Užsienio valstybių diplomatinis korpusas Kaune. Darbai ir dienos, 2002, t. XXX, p. 26-30.

[174] PETRAITYTĖ, Asta. Užsienio valstybių diplomatinis korpusas Kauno kultūriniame gyvenime 1923-1940 metais. Kauno istorijos metraštis, t. III, 2002, p. 144-149.

[175] PETRAITYTĖ-BRIEDIENĖ, Asta. Kultūriniai ryšiai: lietuvių-prancūzų draugija. Darbai ir dienos, 2011, t. LV, p. 225-234. 
[176] PETRUITIS, Jonas. Didysis karas. T. I-III. Kaunas: Žaibas, 1935-1937.

[177] PETRUITIS, Jonas. Didžiojo karo dalyvių veiksmų sumanymai. Prancūzų operacijų planai. Rytas, 1934, rugpjüčio 1, Nr. 173 (3025), p. 5-6.

[178] PETRUITIS, Jonas. Didžiojo karo dalyvių veiksmų sumanymai. Rytas, 1934, liepos 27, Nr. 169 (3021), p. 5; Rytas, 1934, rugpjūčio 4, Nr. 176 (3028), p. 5-6.

[179] PETRUITIS, Jonas. Didžiojo karo dalyvių veiksmų sumanymai. Vokiečių planas. Rytas, 1934, liepos 26, Nr. 168 (3020), p. 5-6.

[180] Pirmas didžiojo karo šūvis. Pirmas Rusijos Vokietijos bei Lietuvos parubežy šūvis. Lietuvos žinios, 1934, rugpjūčio 2, Nr. 174 (4560), p. 3.

[181] P-KIS, J. Kaip jie užsuko baisiojo karo mašiną. Lietuvos žinios, 1934, rugpjūčio 1, Nr. 173 (4559), p. 4-5.

[182] Plano paaiškinimas, 1920 m. sausio 14 d. LCVA, f. 377, ap. 7, b. 231, l. 4-5.

[183] PLEIRYTĖ-PUIDIENĖ, Ona. Audroms siaučiant: apysakos / Vaidilutė. Kaunas: Spaudos fondas, $1931.143 \mathrm{p}$.

[184] POCIŪNAS, Arvydas. Tragiški lietuvių karių likimai Pirmajame pasauliniame kare. Karys, 2001, Nr. 3, p. 25.

[185] Prancūzijos ordinai lietuviams. XX amžius, 1938, lapkričio 17, Nr. 262 (717), p. 10.

[186] Prancūzijos vyriausybès dovana. Karys, 1937, spalio 14, Nr. 42 (969), p. 1200.

[187] Premjera Kinas „Eorum“, grandiozinè prancūziška filma Marnos didvyriai. Lietuvos aidas, 1939, gegužès 15, Nr. 225 (4627), p. 5.

[188] Prieš 20 metų prasidejo pasaulinis karas. Didžiojo Europos gaisro sukaktuvès minint. Lietuvos žinios, 1934, rugpjūčio 1, Nr. 173 (4559), p. 3-4.

[189] Pro Memoria, apie vokiečių karių kapų sutvarkymą Lietuvoje, 1932 m. spalio 7 d. LCVA, f. 383, ap. 7, b. 1484, 1. 24.

[190] Protokolas Nr. 46, 1935 m. lapkričio 22 d. LCVA, f. 945, ap. 1, b. 1, apv. 1. 48.

[191] Prūsų lietuviai, žuvę kovose su rusais ties Kaunu. Trimitas, 1934, gruodžio 13, Nr. 50, p. 968.

[192] PUTINĖLIS. Kauno kapuose ilsisi trijų armijų kariai. Trimitas, 1935, lapkričio 28, Nr. 48 (781), p. 914.

[193] RADUS-ZENKAVIČIUS, Leonas. Im Nebel des Vergangenen. Erinnerungen eines ehemaligen Generalstäblers der alten russischen Armee. Memel: Rytas, 1933. 236 p.

[194] RADUS-ZENKAVIČIUS, Leonas. Trumpas Didžiojo karo eskizas. Kaunas: Vyriausiojo štabo Karo mokslo skyrius, $1924.296 \mathrm{p}$.

[195] RAILA, Bronys. Algirdo sūnūs (Radio vaizdelis kariuomenès šventès proga, lapkričio 23 d.). Karys, 1935, sausis, Nr. 1, p. 10.

[196] Raštas Petrui Ruseckui, 1939 m. vasario 11 d. LCVA, f. 945, ap. 1, b. 60, 1. 19.

[197] RAŠTIKIS, Stasys. Didžiojo karo paliaubų sukaktuvių proga. Trimitas, 1929, lapkričio 14, Nr. 46, p. 765-766.

[198] RAULINAITIS, [Pranas Viktoras]. Dèl sustiprinto prancūzų kalbos mokymo. Ar nereikètų prancūzų gimnazijos? XX amžius, 1938, vasario 17, Nr. 38 (493), p. 7.

[199] REMARQUE, Erich Maria. Kelias atgal. T. I-II. Kaunas: Naujasis Žodis, 1931. 405 p.

[200] REMARQUE, Erich Maria. Trys draugai. Kaunas: Antikvaras, 1939. 287 p.

[201] REMARQUE, Erich Maria. Vakaru fronte nieko naujo. Kaunas: Sakalo b-ve, 1929. 256 p.

[202] RICHTHOFEN, von Manfred. Raudonasai karo lakūnas. Kaunas: Vyriausiojo štabo Karo mokslo valdyba, 1926. 148 p. [vertimo medžiaga: LCVA, f. 929, ap. 6, b. 258].

[203] RIMKA, Albinas. Lietuvos karo nuostoliai. Mūsǔ žinynas, 1923, t. V, Nr. 14, p. 305-319.

[204] Rinktinèse ir būriuose. Alytus. Trimitas, 1934, vasario 22, Nr. 8, p. 159-160. 
[205] Rinktinèse ir būriuose. Kèdainiai. Trimitas, 1930, gegužès 29, Nr. 22, p. 441.

[206] Rinktinèse ir būriuose. Stelmužè. Trimitas, 1931, rugsèjo 3, Nr. 36, p. 710-711.

[207] R-YS. Mūsų karių kapai. Karys, 1924, gegužès 8-14, Nr. 19 (259), p. 161.

[208] RUSECKAS, Petras. Lietuviai kariai vokiečių nelaisvejj. Karys, 1929, gruodžio 19, Nr. 51-52 (551-552), p. 851.

[209] Rusų episkopalinio sinodo vyriausiasis ịgaliotinis karo nuostoliams ir karžygių kapams užsienyje, 1928 m. birželio 28 d. LCVA, f. 391, ap. 4, b. 71, l. 2.

[210] RUTENBERGAS, G. Kas yra didžiojo karo kaltininkas? Lietuva, 1925, rugpjūčio 17, Nr. 181 (1977), p. 1-2.

[211] RUŽANCOVAS, Aleksandras. Dèlei Karo muziejaus ir atskirų dalių muziejų ikūrimo. Karys, 1921, balandžio 28, Nr. 17 (101), p. 190-191.

[212] S. Dar dèl karių kapų. Karys, 1922, rugsėjo 9, Nr. 36 (172), p. 430.

[213] SAFRONOVAS, Vasilijus. Pirmojo pasaulinio karo atminimas Lietuvoje ir Rytų Prūsijoje: naujų tyrimų pradžia. Lituanistica, 2015, t. 61, Nr. 3 (101), p. 149-159.

[214] Savivaldybès rūpinsis rusų karių kapais. Trimitas, 1936, birželio 18, Nr. 25 (810), p. 594.

[215] Sąrašas kapinių ir atskirų laike pasaulinio karo žuvusiųjų Lietuvos neokupuotoje dalyje rusų karių, karo nelaisvių bei civilių asmenų, 1928 m. lapkričio 19 d. LCVA, f. 391, ap. 4, b. 71, 1. 67-89.

[216] Sąrašas knygų, padovanotų Prancūzijos Respublikos Vyriausybès kariuomenès bibliotekai, 1937 m. LCVA, 929, ap. 6, b. 208, 1. 396-402.

[217] SCANLON, William T. Dieve, pasigailèk mūsų! Didžiojo karo (1918 metų) apysaka - amerikonų „Vakarų fronte nieko naujo“. Marijampolè: [s. n.], 1932. 400 p. [God Have Mercy On Us!: A Story of 1918 by William T. Scanlon].

[218] SIMONAITYTĖ, Ieva. Vilius karalius. T. I. Kaunas: Švietimo ministerijos Knygų leidimo komisija, 1939. $445 \mathrm{p}$.

[219] SKORUPSKIS, Vladas. A. Uspenskio „Kare“. Naujoji Romuva, 1932, gegužès 15, Nr. 20 (72), p. 477.

[220] SKRIPKAUSKAS, Antanas. Romanas be moters: epizodas iš Didžiojo karo laikų. Šiauliai: [s. n.] , 1932. 209 p.

[221] Sofijos Smetonienès žodis šaulių pusvalandžio metu balandžio 9 d. Trimitas, 1938, balandžio 14, Nr. 15 (904), p. 367.

[222] STALIŪNAS, Darius. Žuvusių karių kultas tarpukario Lietuvoje. Lietuvių Atgimimo istorijos studijos, 2001, t. 17, p. 120-132.

[223] STANAITIS, [Simas]. Žvilgsnis ị praeiti. Lietuvos karo invalidas, 1938, Nr. 1, p. 8.

[224] STANKAITIS. Didysis karas (20 metų nuo jo pradžios). Karys, 1934, rugpjūčio 2, Nr. 31 (802), p. 611-614.

[225] S-TIS, V. [STEPONAITIS, Vytautas]. Klaikuma. Kardas, 1931, kovas, Nr. 3 (23), p. 44-45.

[226] STR. S. Mūsų karių kapai. Kardas, 1926, kovo 30, Nr. 9 (33), p. 130.

[227] Svetimos kariuomenès. Latvija. Kardas, 1925, birželio 1, Nr. 10, p. 15.

[228] Š. Š. Didijj karą beminint. Trimitas, 1924, rugpjūčio 7, Nr. 199, p. 10-12.

[229] ŠAPOKAS, J. Iš kariuomenės gyvenimo. Alytaus kapuose. Karys, 1923, rugsëjo 20-26, Nr. 38 (226), p. 428.

[230] ŠAULĖ MARIA. Motina, Trimitas, 1933, gegužès 4, Nr. 18, p. 351-352.

[231] Šauliai tvarkys kapus. Trimitas, 1930, kovo 27, Nr. 13, p. 258.

[232] Šaulių gyvenimas. Griškabūdis. Trimitas, 1940, birželio 13, Nr. 24 (1017), p. 598.

[233] ŠAULYS ŠAUKLYS. Dar pavojus. Trimitas, 1925, vasario 19, Nr. 7, p. 193.

[234] ŠEMERYS, Salys. Granata krūtinèj [eilèraščiai]. Kaunas: keturių vèjų leidinys, 1924. 30 p. 
[235] Šiandien Kaune minima Didžiojo karo paliaubų 20 m. sukaktis. Lietuvos aidas, 1938, lapkričio 11, Nr. 511 (4320), p. 5.

[236] Šūvis, ǐžiebęs Didịj karą. Austro Vengrijos sosto ịpėdinio Pranciškaus Ferdinando nužudymas. Lietuvos žinios, 1934, birželio 28, Nr. 145 (4531), p. 3; 1934, birželio 30, Nr. 146 (4532), p. 3; 1934, liepos 2, Nr. 147 (4533), p. 3; 1934, liepos 3, Nr. 148 (4534), p. 4; 1934, liepos 4, Nr. 149 (4535), p. 4; 1934, liepos 5, Nr. 150 (4536), p. 4; 1934, liepos 6, Nr. 151 (4537), p. 4; 1934, liepos 9, Nr. 153 (4539), p. 4; 1934, liepos 10, Nr. 154 (4540), p. 4.

[237] Taip Lietuva sutiko D. karo paliaubas. Lietuvos aidas, 1938, lapkričio 11, Nr. 512 (4321), p. 6.

[238] TAUTIETIS. Žmonijos žaizda. Trimitas, 1925, birželio 18, Nr. 23, p. 756.

[239] TUMAS, Kazys. Šaulių fiziškas lavinimas. Trimitas, 1938, gegužès 26, Nr. 21 (910), p. 500-501.

[240] Tvarko karių kapus. Karys, 1930, balandžio 10, Nr. 15 (567), p. 304.

[241] URM 1919 m. rugsèjo 15 d. raštas. LCVA, f. 377, ap. 9, b. 29, 1. 12.

[242] URM 1920 m. lapkričio 23 d. raštas VRM. LCVA, f. 377, ap. 9, b. 29, 1. 27.

[243] USPENSKIS, Aleksandras. Didžiajame kare: Lietuva - Rytu Prūsija 1914-1915 m. Karininko atsiminimai su didž. karo vaizdais ir kovu schemomis. Kaunas: Sakalas, 1935. 239 p.

[244] V. Nepriklausomos Lietuvos pirmas dešimtmetis. Trimitas, 1928, vasario 16, Nr. 7, p. 215-220.

[245] V. S. Didžiojo karo romanai. Kardas, 1930, kovas, Nr. 3 (11), p. 38-40.

[246] V. Steponaičio 1936 m. liepos 30 d. laiškas Rapolui Krivečkai (Pagyriai). LCVA, f. 929, ap. 6, b. $187,1.227$.

[247] VAIČIŪNAS, A. Kuo pats kvepia, tuo ir kitą tepa? Trimitas, 1926, vasario 25, Nr. 8, p. 238-239.

[248] VAIČIŪNAS, V. Džiova. Trimitas, 1926, sausio 14, Nr. 2, p. 52-53.

[249] Valstybès Prezidento kalba gruodžio 8 d., minint Lietuvių Komiteto dvidešimties metų sukaktị. Trimitas, 1934, gruodžio 13, Nr. 50, p. 957-958.

[250] Valušiené apdovanota Garbès legiono ordinu. Lietuvos aidas, 1939, vasario 3, Nr. 54 (4456), p. 5. [251] VAREIKIS, Vygantas. Karo žymè: pasaulio vaikystės pabaiga. Kultūros barai, 2016, Nr. 3, p. 86-92.

[252] VIENAS APSIVILUSIŲ. Patriotizmas ir atsidèkojimas. Kardas, 1925, gegužès 1, Nr. 8, p. 4.

[253] VIKTORAS VYTENIETIS. Šauliai sutvarkè kapus. Karys, 1934, gegužè 1, Nr. 22 (793), p. 437.

[254] VIRPA, B. Mūsų pamirštieji. Lietuva, 1925, vasario 10, Nr. 33 (1829), p. 2.

[255] Vokiečių kariuomenès ir Amerikos Raudonojo Kryžiaus atstovai Lietuvoje. Karys, 1928, gegužès 16-31, Nr. 21-22 (469-470), p. 419-421.

[256] Vokiečių karo kapinių globojimas 1921 m. LCVA, f. 377, ap. 9, b. 29, 1. 38-130.

[257] VRM Tikybų departamentas, 1919 m. rugsèjo 18 d. LCVA, f. 377, ap. 9, b. 29, 1. 13.

[258] VRM Tikybų departamento 1919 m. rugsėjo 19 d. raštas apskričių viršininkams. LCVA, f. 377, ap. 9 , b. $29,1.14$.

[259] Ž. Vakarų fronte nieko naujo. Kardas, 1929, gruodis, Nr. 8, p. 112-121.

[260] ŽADEIKA, Vaclovas. Karo veiksmai Rytprūsiuos 1914 m. rugp. - rugs. m. I dalis. Generalinio štabo kursai I-ji laida. Kaunas: Generalinio štabo kursų leidinys, 1932.67 p.

[261] ŽADEIKIS, Pranciškus. Didžiojo karo užrašai. I dalis. 1914-1915-1916 metai. Klaipèda: Lituanika, 1921.

[262] ŽEMAITIS, B. Vertimai. Vairas, 1935, spalis, t. XV, Nr. 10, p. 248-249.

[263] Z̆-KAS, J. Penkiolika metų. Trimitas, 1938, sausio 20, Nr. 3 (892), p. 56-58.

[264] ŽL. Didžiojo karo pradžios sukaktis. Lietuvos aidas, 1934, liepos 28, Nr. 170 (2137), p. 7-8.

[265] ŽUTAUTAS, V. Kauno karių kapinès. Kardas, 1926, vasario 20, Nr. 5 (29), p. 72.

[266] Žuvusieji kariai. Karys, 1927, spalio 26 - lapkričio 2, Nr. 43 (439), p. 385-386. 
[267] Žuvusiųjų gerbimas. Karys, 1925, sausio 1-7, Nr. 1 (293), p. 7.

[268] ГРОМОВ, Моисей. Karas Lietuvoj. Brokoly, N. Y.: Dienraštis Laisve, 1933. 223 p.

VYTAUTAS JOKUBAUSKAS

\section{The Great War: Discourses and Remembrance Practices in Interwar Lithuania}

\section{Summary}

The paper offers analysis of the discourses on the Great War (World War I) and of the practices of the culture of remembrance in interwar Lithuania. The research addresses the scope and the nature of literary fiction dealing with the theme of the Great War in interwar Lithuania (with the focus on the literary merits of translated works by foreign authors and of those by local authors, the 'upsurge' of and changes in the fiction on war), and the significance of the war to the public at large; the research also expands on the practices of the commemoration of the Great War and on the maintenance of military cemeteries in interwar Lithuania.

On the one hand, literature on war in interwar Lithuania was an object of analysis, while, on the other hand, it represented a field of publishing industry with the works by foreign authors translated and local authors published. The Great War was a landmark event for a whole generation. It changed people's lives and attitudes to war, and opened up new horizons for war fiction. Multitudes of young gifted people had to spend several years at the front because of universal conscription. Later they wrote books often based on their own experience, or even their diaries, that became literary classics. In Lithuania translated works came first: the publication of the novel All Quiet on the Western Front can be considered a turning point that was followed by the works of Lithuanian authors. In a sense, the 1930s were a time of a breakthrough for the literature on the subject of the Great War in Lithuania.

Certain episodes of the Great War, such as its outbreak and causes, the German occupation, and the military actions reflecting the war experience of the Lithuanians (1914 in East Prussia, the battle of Augustów in 1915, and the fall of Kaunas Fortress) were actualised in interwar Lithuania. Such a situation stemmed from geographical and national reasons: the said operations took place on the 'Lithuanian lands' with numerous involvement of the Lithuanians. There were controversial judgements on the war: on the one hand, it had caused heavy casualties and immense material losses leading to moral decay and changes in the heretofore familiar mode of life and mindset. On the other hand, the war 'woke up' the Lithuanian nation and created conditions for the restoration of the Lithuanian state, which was straightforwardly referred to as a true miracle and was thought impossible were it not for the Great War (followed by the fall of three European empires). The casualties of the Great War therefore came to be seen as a sacrifice on the 'altar of freedom' of Lithuania and this claim was further reinforced by the fact that a great number of Lithuanian soldiers took part in the Great War serving in the armies of other countries (in particular those of Russia, Germany, and the United States) and many of them perished on various fronts. 
The war was a consistent theme in the public discourse of interwar Lithuania, coming up now and then, touching upon different practices related to the ritual of remembrance of the war. Commemorations of the Great War anniversaries had distinct political connotations and transformed in relation to the developments in the Lithuanian foreign policy of that time. The Lithuanian-French Association, the members of which included influential figures of Lithuania of the time, was actively involved in these activities, therefore the Lithuanians and the French, along with Lithuania and France, had to be brought closer together through the experience of common fighting and by the threat of a common enemy (Germany). Furthermore, references and suggestions could be found that Lithuanians were involved in the defence of France (fighting in East Prussia in 1914 and later on as part of the US Army on the Western Front).

The question of the maintenance and upkeep of the graves and military cemeteries of the Great War had a marked national aspect. From 1919, the Volksbund was in charge of the maintenance of German war graves. The Lithuanian press constantly referred to the example of neighbouring Latvia where the upkeep of the Great War military cemeteries started even before the end of the war. The attitude of the Lithuanian public and institutions toward the war graves can be split into two stages before and after 1927. The practice of the maintenance of war graves was rare during the first period: even the graves of the fighters for independence were neglected and forgotten during that time, while the graves of the Great War soldiers were sometimes subjected to disrespectful treatment. In 1927 a systematic maintenance and upkeep of the graves of the fighters of the Wars of Independence was launched according to the German and Latvian pattern, and eventually consideration was given to the maintenance of the Great War military cemeteries as well, with actual work recorded in the 1930s.

Keywords: the Great War (World War I), discourse, military cemetery, literature on war, war losses, Lithuanian-French Association 